\title{
CIÊNCIA DOS JOGOS APLICADA A EDUCAÇÃO: UM ESTUDO DO PROCESSO CRIATIVO DE CONFECÇÃO DO JOGO ANALÓGICO UMUECHEM
}

\author{
Jeferson Antunes (UFC)* \\ http://orcid.org/0000-0002-2969-5788 \\ Verônica Salgueiro do Nascimento (UFC)** \\ http://orcid.org/0000-0002-4903-5445 \\ Zuleide Fernandes de Queiroz (PRODER/UFCA) ${ }^{* * *}$ \\ http://orcid.org/0000-0003-3174-4750
}

\section{RESUMO}

O presente estudo tem por objetivo demonstrar o processo criativo de concepção do jogo analógico Umuechem, utilizando a metodologia do Ciclo Criativo de Jogos Colaborativos, além de descrever seu processo de criação a partir das escolhas subjacentes aos objetivos perquiridos pelo jogo e refletir sobre a ação interdisciplinar no processo de criação do jogo. Este é apresentado sob a forma de relato do processo de criação de jogos educativos utilizando uma metodologia científica que auxilia a gestão dos processos e a descrição detalhada do objeto de pesquisa. 0 jogo estudado foi criado na Universidade Federal do Cariri, com o objetivo de discutir o tema da sustentabilidade no âmbito da educação superior, inovando o processo de ensino-aprendizagem a partir da mediação dos saberes de forma lúdica. Como resultados, ele apresenta-se como uma contribuição para a educação, propiciada por uma base científica interdisciplinar, repleta de referências ligadas ao design de jogos, educação, história, literatura e estatística; o processo não é aleatório, mas intencional, pensado a partir do público-alvo e de objetivos educacionais bem delimitados.

Palavras-chave: Jogos colaborativos. Ciclo Criativo de Jogos Colaborativos. Design de jogos.

* Doutorando em Educação pela Universidade Federal do Ceará (PPGE/UFC). Mestre em Desenvolvimento Regional Sustentável pela Universidade Federal do Cariri (PRODER/UFCA). E-mail: jeferson.kalderash@gmail.com

** Pós-Doutorado em Psicologia pela Universidade Federal do Rio de Janeiro (UFRJ). Doutora em Educação pela Universidade Federal do Ceará (UFC). Professora adjunta da Universidade Federal do Ceará (UFC). E-mail: vesalgueiro@gmail.com

*** Pós-doutorado em Educação pela Universidade Federal do Rio Grande do Norte (UFRN). Doutora em Educação pela Universidade Federal do Ceará (UFC). Professora Colaboradora do Programa de Pós-Graduação Interdisciplinar em Desenvolvimento Regional Sustentável da Universidade Federal do Cariri (PRODER/UFCA). E-mail: zuleidefqueiroz@gmail.com 


\section{ABSTRACT}

GAMES SCIENCE APPLIED TO EDUCATION: A STUDY OF THE CREATIVE PROCESS OF CREATING THE UMUECHEM ANALOGUE GAME

The present study aims to demonstrate the creative process of designing the analog game Umuechem, using the methodology of the Creative Cycle of Collaborative Games, as well as describing its creation process based on the choices underlying the objectives of the game and reflecting on the interdisciplinary action in the process of creating the game. This is presented in the form of an account of the process of creating educational games using a scientific methodology that assists the management of the processes and the detailed description of the research object. The game studied was created at the Federal University of Cariri, with the objective of discussing the theme of sustainability in higher education, innovating the teaching-learning process through the mediation of knowledge in a playful way. As results this presents itself as a contribution to education, propitiated by an interdisciplinary scientific based, replete with references related to game design, education, history, literature and statistics; the process is not random, but intentional, thought from the target audience and well-defined educational goals.

Keywords: Collaborative games. Creative Cycle of Collaborative Games. Game design.

\section{RESUMEN}

\section{CIENCIA DE LOS JUEGOS APLICADA A LA EDUCACIÓN: UN ESTUDIO DEL PROCESO CREATIVO DE CREACIÓN DEL JUEGO ANALÓGICO UMUECHEM}

Este estudio tiene como objetivo demostrar el proceso creativo de diseño del juego analógico Umuechem, utilizando la metodología del Ciclo Creativo de Juegos Colaborativos, además de describir su proceso de creación a partir de las elecciones subyacentes a los objetivos que persigue el juego y reflexionando sobre la acción interdisciplinar en el proceso de creación del juego. Este se presenta en forma de informe sobre el proceso de creación de juegos educativos utilizando una metodología científica que asiste en la gestión de los procesos y la descripción detallada del objeto de investigación. El juego estudiado fue creado en la Universidad Federal de Cariri, con el objetivo de discutir el tema de la sostenibilidad en el contexto de la educación superior, innovando el proceso de enseñanza-aprendizaje a partir de la mediación del conocimiento de manera lúdica. Como resultado, se presenta como un aporte a la educación, provisto de una base científica interdisciplinar, llena de referencias relacionadas con el diseño de juegos, la educación, la historia, la literatura y la estadística; el proceso no es aleatorio, sino intencional, diseñado en función de la audiencia objetivo y objetivos educativos bien definidos.

Palabras clave: Juegos colaborativos. Ciclo creativo de juegos colaborativos. Diseño de juego. 


\section{Introdução}

A utilização de jogos na educação não é uma novidade. Na busca por novos métodos e técnicas que possam motivar estudantes, profissionais da educação têm recorrido ao lúdico como estratégia para dinamizar suas aulas. Os jogos são uma manifestação da cultura, que emergem em todas as sociedades, sendo estudados por diversas áreas do conhecimento científico (CAILOIS, 1990; HUIZINGA, 2000).

Na educação, a educação infantil e a psicologia do desenvolvimento têm-se ocupado desse campo. Elas tencionando essas manifestações culturais em sala de aula por meio de estudos que consideram os jogos e o brincar como importantes ferramentas de desenvolvimento infantil.

Para além de motivar estudantes, outras questões estão postas na educação e também influenciam o uso de jogos. As discussões sobre didática e currículo ensejam uma aproximação entre os saberes educativos e a atitude do profissional da educação em sala de aula, repensando seu papel a partir do paradigma da transmissão do conhecimento pronto e acabado; em outra concepção, um profissional capaz de mediar conhecimentos dentro do processo de ensino-aprendizagem.

Nesse ínterim, uma diversidade de tipos de jogos: individuais, competitivos, cooperativos e colaborativos; eletrônicos, analógicos, mistos; serious games e a gamificação, se apresam como estratégias para a mediação desses saberes, buscando uma maior imersão do estudante a partir da simulação de ambientes e da resolução de problemas, para que possam contribuir significativamente nos processos de ensino-aprendizagem.

Quando pensamos a educação como construção horizontal de conhecimento (FREIRE, 1996), a cooperação e a colaboração são importantes ferramentas no diálogo entre a educação e os jogos. Dentro desse escopo, os jogos cooperativos/colaborativos têm oferecido uma importante contribuição. São jogos em que todos ganham ou todos perdem, os participantes são parceiros que têm metas comuns e buscam, em conjunto, atingir os objetivos propostos pelo jogo (ALMEIDA, 2010, 2011).

Os jogos cooperativos têm como contribuição possível o trabalho em grupo, no qual todos juntos constroem estratégias para a resolução de problemas, pactuados pelo diálogo e a interação, existindo um nível importante de sensibilização dos participantes através do impacto lúdico significativo que o jogo pode causar (ANTUNES et al., 2016).

Compreendendo essas questões conceituais do campo dos jogos ligados à educação, os seguintes questionamentos tomam nossas mentes: existe algum método que auxilie educadores no processo criativo de confecção de jogos? Como demonstrar o processo criativo de confecção de jogos? Quais os conhecimentos necessários para se criar um jogo?

Tendo em vista contribuir com essas perguntas de pesquisa, o presente estudo tem por objetivo demonstrar o processo criativo do jogo analógico Umuechem, utilizando a metodologia do Ciclo Criativo de Jogos Colaborativos. Como demais objetivos vamos descrever o processo de criação do jogo, a partir das escolhas subjacentes aos objetivos perquiridos pelo jogo, $\mathrm{e}$ refletir sobre a ação interdisciplinar no processo de criação do jogo.

Para tanto, apresentamos este estudo sob a forma de um relato de experiência da confecção do jogo centrado no método do Ciclo Criativo de Jogos Colaborativos, método estipulado para dar suporte ao processo criativo de jogos e sua descrição, um aporte técnico-científico que auxilia profissionais da educação, designers e cientistas dos jogos na tarefa de incubar esse processo criativo.

0 processo estudado tem a participação dos membros do Laboratório Interdisciplinar de Jogos Colaborativos (LIJC) ${ }^{1}$ da Universidade Federal do Cariri (UFCA) e de um grupo de designers ${ }^{2}$ prospectado para atividades técnicas necessárias à prototipação de jogos. Esse jogo

1 Aqui chamados de equipe criativa.

2 Aqui chamados de equipe de designers. 
foi concebido entre os anos de 2017 e 2018, com a intenção de discutir um tema ligado à sustentabilidade, tendo como público-alvo estudantes de ensino superior da UFCA.

Como resultado deste estudo apontamos a importância de pensar o processo com bases científicas e técnicas, a partir de referências estruturadas para que o jogo possa dialogar com a realidade do público-alvo e, além disso, equilibre a diversão e seus objetivos educacionais de forma clara e coesa.

0 presente estudo se justifica pela pouca literatura que dê suporte para que profissionais da educação possam incubar processos criativos que culminem em jogos que possam impactar significativamente seus estudantes, sendo uma contribuição para o campo científico, uma vez que são raros os estudos acerca de processos criativos e para a confecção de jogos educativos embasados em métodos científicos, sobretudo quando o público-alvo da ferramenta de mediação do conhecimento é do ensino superior. Indo além, o estudo demonstra como um grupo de estudantes e professores do ensino superior pode dar vazão a processos criativos que gerem produtos que podem impactar o próprio sistema educativo no qual estão inseridos, perquirindo uma contribuição social importante ao campo da educação superior, que tem poucos estudos e produtos ligados ao nosso objeto do conhecimento.

\section{Metodologia}

O processo criativo de confecção do jogo utiliza o Ciclo Criativo de Jogos Colaborativos, um método que sistematiza o processo de criação e sua descrição, que tem por objetivo nortear equipes de designeres que desejem criar jogos de caráter educativo (ANTUNES et al., 2018). Esse método conta com uma série de fases interdependentes: pesquisa bibliográfica, definição de objetivos, definição do ambiente, escolha de plataforma, definição de metas, definição de regras, definição do sistema de feedback, testes, avaliação, revisão e o possível lançamento (ANTUNES et al., 2018).

No presente estudo descrevemos cada uma das etapas que compõem o método escolhido para a criação do jogo, apresentando as motivações que nortearam cada uma das escolhas, bem como a literatura subjacente a essas decisões. 0 processo criativo ocorreu entre 2017 e 2018, no qual a equipe do LIJC, juntamente com um grupo de designers contratados para ilustração e modelagem 3D, coproduziram o artefato. Várias etapas do processo de prototipação contaram com trabalhos manuais (pintura, colagem), além do trabalho do designer artístico.

Baseados no aporte conceitual, discutiremos os aspectos de design de jogos que fomentaram sua concepção, dialogando sobre o tema, o ambiente controlado propiciado pelo jogo, suas metas, regras, sistema de feedback e mecanismos de participação dos jogadores e jogadoras.

\section{Declaração de objetivos educacionais}

Para se criar um jogo educativo refletimos, a todo momento desse processo, sobre quais são os objetivos educacionais desse jogo. Partindo da ideia de que o jogo é uma ferramenta que deve ser utilizada com um propósito explícito (KISHIMOTO, 2010) no percurso de design, chegamos à conclusão que ele possui três objetivos: a) proporcionar a resolução de situações-problema por meio do trabalho em grupo; b) trabalhar a tomada de decisão frente aos problemas propostos de forma colaborativa; e c) ser uma ferramenta que medeie a reflexão sobre a sustentabilidade.

Esses objetivos são essenciais para compor o jogo. Uma vez que seu caráter é educativo, eles servem para guiar o processo criativo e são componentes essenciais para sua avaliação, logo, devem ser alvo de análise.

Entre as habilidades e competências que pretendemos destacar estão: mediação de conflitos, gestão de recursos, raciocínio lógico, interpretação de papéis, resolução de situações -problema, tomada de decisões, capacidade 
de previsão de resultados e o diálogo. Essas são importantes habilidades e competências que são úteis ao longo da vida do estudante e necessárias para a vitória nesse jogo.

0 jogo é formatado para cinco participantes por vez, com uma duração aproximada de 1 hora e 40 minutos, incluindo o tempo de explicação e de partida. Tomamos tal tempo pedagógico como base na carga horária normal da Universidade Federal do Cariri (UFCA) de 2 horas para cada aula em disciplinas de 64 ou 32 horas.

\section{Ambiente controlado a partir do jogo cooperativo}

Propiciar aos participantes um ambiente controlado é a base para se criar um jogo, sendo essa sua planta baixa (SCHUYTEMA, 2008), podendo ser escolhida a partir de uma situação-problema que seja significativa ${ }^{3}$ aos participantes e colabore com o tema da atividade de ensino-aprendizagem necessária ao espaço educativo onde será implementado.

Nossa escolha se deu pelo tema da sustentabilidade, visto ser um problema que aflige as sociedades de forma global, atual, e que está em evidência desde a década de 1970 (ANTUNES; NASCIMENTO; QUEIROZ, 2017). Nossa planta baixa foi escolhida a partir do caso apresentado por Alier (2015), no qual a Shell explorou recursos petrolíferos no delta do Níger, protegido pelas forças armadas de um governo ditatorial, sendo que os bens e serviços ofertados pela natureza tiveram acesso negado aos povos Ogoni; esse fato ocasionou revoltas populares contra os campos de extração petrolífera da Shell por parte destes povos, culminando em episódios de violência e morte.

0 episódio escolhido retrata um conflito ecológico distributivo, no qual o acesso aos bens e serviços que a natureza oferece a uma comunidade tradicional foram negados, usando do discurso da modernização e geração de

3 Semelhante ao que encontramos na aprendizagem baseada em problemas e na aprendizagem baseada em projetos (BERBEL, 2011), esse problema é motivador dos estudantes para mobilizar sua participação. emprego e renda para a região. 0 fato é que aos povos tradicionais que viviam da extração sustentada foi oferecido apenas opressão, violência e morte como moeda de troca.

Dessa forma, escolhemos, a partir desse jogo, narrar um pouco dessa história através do lúdico. Os participantes, dentro do jogo, são moradores de Umuechem, território Ogoni, que esteve ligado diretamente ao conflito que desejamos explorar. Sendo membros desta vila, a ideia central é a de que eles colaborem para a prosperidade de todos.

Como escolha no processo de design, ${ }^{4}$ preferimos criar um jogo de tabuleiro, analógico, tendo em vista a facilidade para a aplicação, ${ }^{5} \mathrm{a}$ possibilidade de interação com os componentes dos jogos e com os outros participantes. Projetamos então, para esse jogo cooperativo, alguns elementos simbólicos que remetem à planta baixa do jogo: um mapa fictício do território onde está a vila, ilustração de personagens dos jogadores, algumas miniaturas de árvores, blocos que representam recursos naturais, miniaturas que representam construções possíveis na vila. A Figura 1 mostra alguns desses elementos.

Figura 1 - Mapa do território de Umuechem

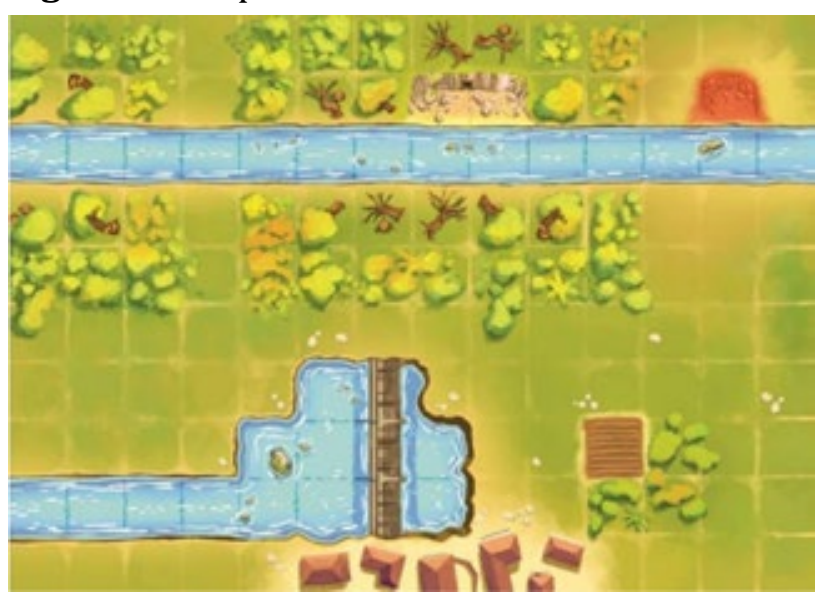

Fonte: Elaborado pela equipe de design em parceria com a equipe criativa.

4 Dentro do processo de design do jogo, além do autor e dos colaboradores do LIJC (que formam a equipe criativa), foram contratados pelo autor uma equipe de três designers composta por um desenhista, um ilustrador digital e um profissional de manipulação de objetos em 3D.

5 Os colaboradores do LIJC demonstraram, durante as discussões sobre a criação do jogo, já ter experiência com a aplicação de jogos de tabuleiro. 
0 mapa é dividido em quadros de $5 \mathrm{~cm} \mathrm{X} 5$ $\mathrm{cm}$, com medida total de $70 \mathrm{~cm} \mathrm{X} 50 \mathrm{~cm}$, para uma melhor compreensão das regras do jogo e visualização espacial. Na parte sul-central está representada a vila de Umuechem, com a visão aérea das casas e construções que pertencem ao vilarejo. Para sua composição, a equipe criativa sistematizou o escopo inicial, utilizado pelos designers para sua ilustração final.

Figura 2 - Escopo inicial do mapa de Umuechem

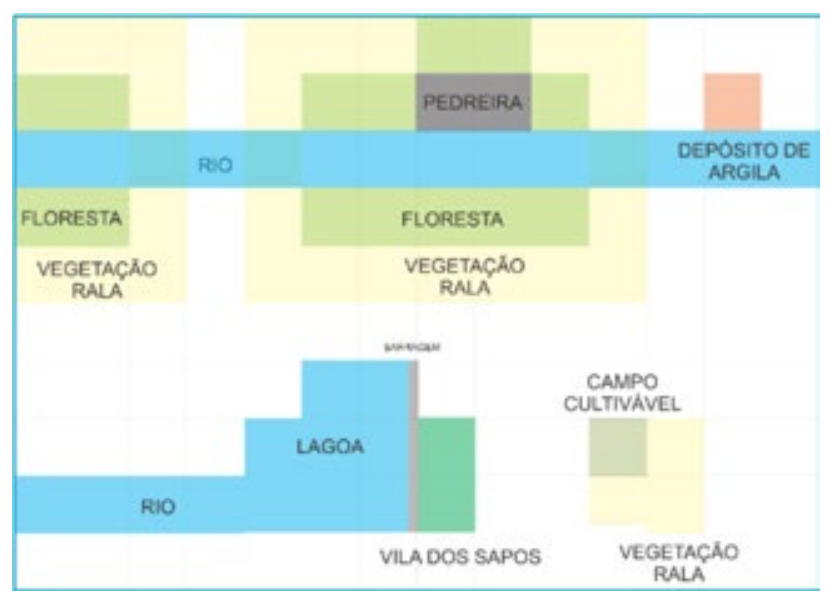

Fonte: Elaborado pela equipe criativa.

A nordeste da vila se situa um campo de plantação, que na narrativa do jogo é utilizado pelos habitantes para adquirir alimentos vegetais; a noroeste da vila temos um lago represado. No quadrante norte do mapa temos uma pedreira e uma olaria, que, dentro das regras do jogo, são fontes de recursos para a vila. Dentro do quadrante norte temos várias árvores e arbustos que compõem a vegetação, ilustrados a fim de parecerem destruídos; essa escolha foi feita para maximizar a possibilidade de interpretação dos participantes. Acima de cada um desses espaços devastados colocamos miniaturas de árvores impressas em 3D; desta forma, quando uma árvore é destruída, retirase do jogo a miniatura e a ilustração apresenta/ representa a devastação.

Este modelo 3D de árvore é impresso em três partes: sua base (parte redonda), tronco e copa. Cada um destes elementos foi pintado separadamente a mão, com o objetivo de apresentar uma paleta de cores semelhante, porém demonstrando pequenas variações de cores e texturas. As peças foram coladas após a pintura, sendo confeccionadas um total de 38 árvores. Nosso objetivo é que os participantes possam apreciar tais diferenças ao manipular as peças.

Figura 3 - Modelo 3D utilizado para confecção das árvores do jogo

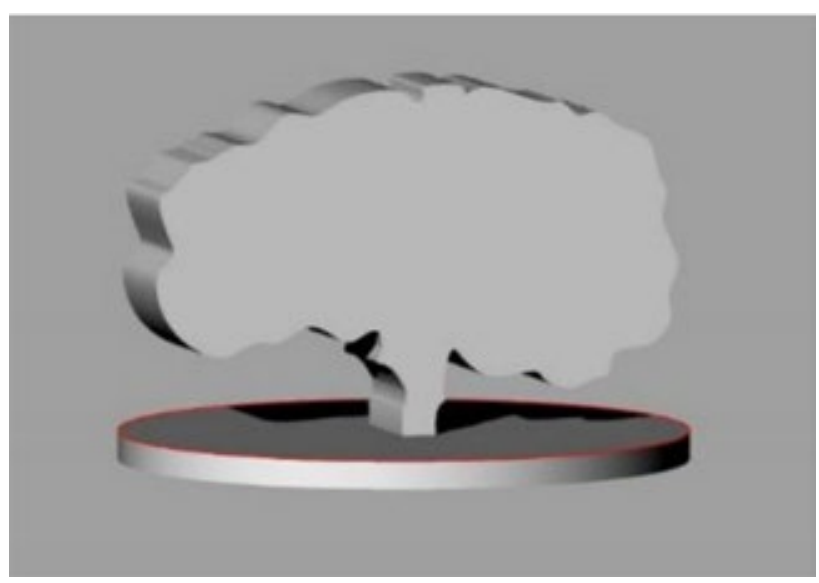

Fonte: Elaborado pela equipe de design em parceria com a equipe criativa.

Figura 4 - Árvores pintadas e montadas

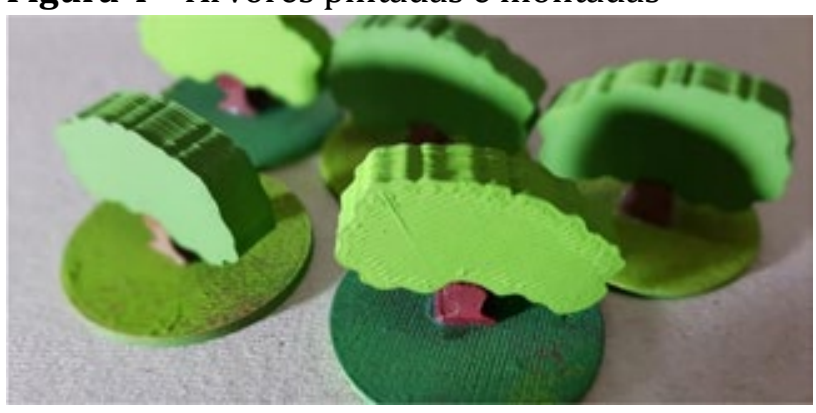

Fonte: Acervo dos autores deste artigo.

Visando uma maior interação entre os jogadores, numa interlocução criativa entre o jogo proposto e as características das metodologias ativas e da educação colaborativa (BERBEL, 2011; BRUFFEE, 1995), estabelecemos papéis que cada um dos participantes deve realizar no jogo. Estes papéis estão diretamente ligados ao cotidiano da vila, sendo a interação entre os diferentes papéis fundamental para que seja alcançada a meta do jogo.

Os papéis são: Líder da aldeia, Carpinteiro, Mineradora, Agricultor e Ambientalista. Cada um destes papéis tem funções específicas, 
com regras específicas dentro do jogo, sendo úteis para que cada jogador, a partir do momento que compreende as regras, possa ter e utilizar funções específicas. Inspiramo-nos aqui nos jogos de Role Playing Game (RPG), um jogo cooperativo que tem por objetivo o contar histórias - os participantes ficam sentados no entorno de uma mesa com livros, dados, fichas de personagens, lápis, borracha, mapas e ilustrações. A estrutura desse jogo cooperativo admite papéis para cada um dos participantes, normalmente um deles assume o papel de narrador ou mestre do jogo e os demais constroem ${ }^{6}$ personagens específicos (geralmente heróis) que vão interpretar dentro da história.

Os personagens desse jogo são construídos previamente, visando tanto uma maior interação e funções específicas, como diminuir o tempo do jogo, já que quando os jogadores (como acontece nos jogos de RPG) constroem seus próprios personagens, esse processo remete-se a algum tempo e estudo. Nosso foco aqui está em representar situações de trabalho da vida cotidiana que contribuem para o desenvolvimento da vila de Umuechem.

Figura 5 - Ilustração dos personagens; da esquerda para direita: Agricultor, Ambientalista, Líder da vila, Carpinteiro e Mineradora

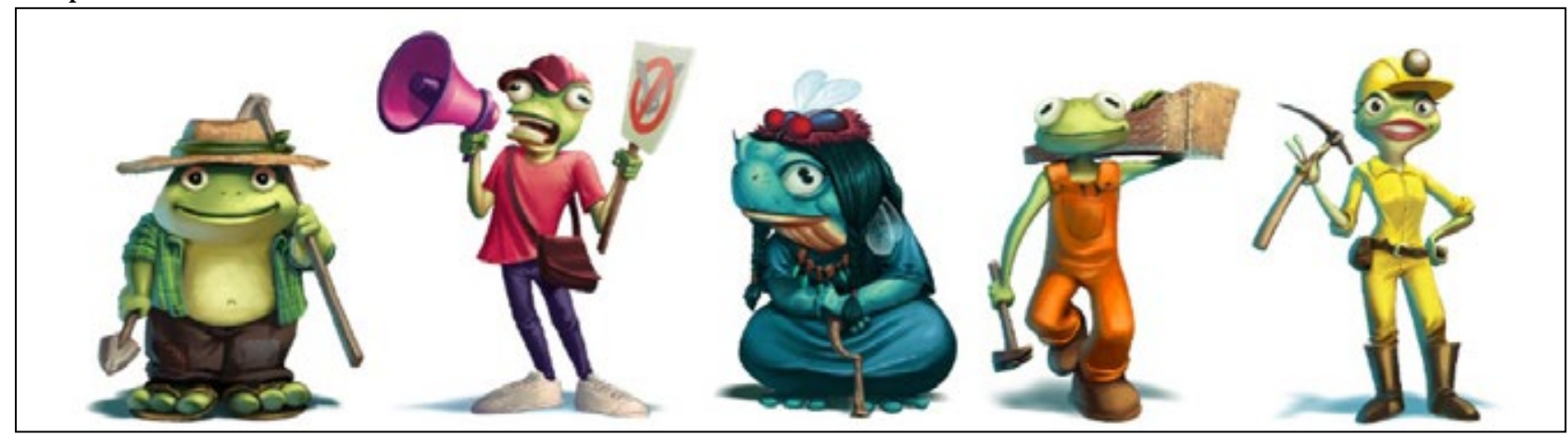

Fonte: Ilustrações criadas pela equipe de design com base nas opções fornecidas pela equipe criativa.

A equipe criativa escolheu cada um dos elementos como forma de dar significado às imagens que ilustram o jogo, de forma que sua interpretação possa servir à interpretação do jogador, contribuindo com os elementos lúdicos por meio da interação lúdica significativa (SALEN; ZIMMERMAN, 2012).

Tomamos como ideia a escolha de representar os personagens dos jogadores como sapos, ao discutirmos tais representações à luz de uma observação feita por Alier (2015), que entende que o sapo representa equilíbrio em um ecossistema natural, pois sua presença em lagos denota vida naquele ecossistema.

As ilustrações, portanto, carregam esse significado, mas seu uso antropomórfico, ao hibridizarmos a figura humana com a de um sapo, remete ao lúdico, à imaginação; "a vertente fantástica que adota é a vinculada ao lúdico e ao mágico, ao humor surrealista, buscando a aliança entre renovação estética e compromisso social" (SCHMITT, 2015, p. 114).

Essa renovação estética antropomórfica nos possibilita uma releitura, aliando a profissão, o animal e o humano na busca de estabelecer outros significados que são interpretados pelo jogador. Cada um dos personagens apresentados tem funções específicas. No que concerne às regras, cada jogador recebe uma ficha que contém a ilustração, alguns dados e regras específicas do personagem escolhido - no tabuleiro é representado por uma miniatura de

6 Quando falamos em construir o personagem estamos falando em sentido literal. 0 jogador usa das regras para dizer como será seu personagem estatisticamente, usando a ficha de personagem, e deve também escrever a história do personagem que está construindo, ilustrá-lo e contar aos outros participantes como é o temperamento dele e sua história. 
sapo, impressa em 3D, pintada a mão, na cor que representa seu personagem.

Figura 6 - Miniaturas utilizadas no tabuleiro; da esquerda para a direita temos as miniaturas do Agricultor, Carpinteiro, Ambientalista, Líder da vila e Mineradora

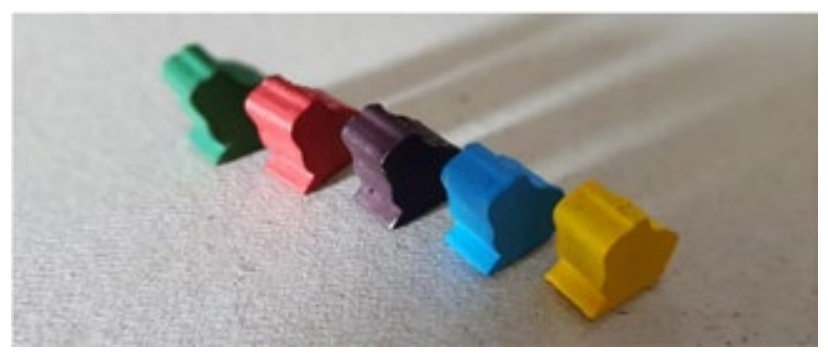

Fonte: Acervo dos autores deste artigo.

A escolha das ilustrações por gênero é uma forma de demonstração de nosso entendimento que os papéis sociais não devem ser designados de tal forma. A líder da vila é a representação de uma mulher, sendo comum a sociedades matriarcais, mas incomum na realidade brasileira. A profissão ligada à mineração, por sua vez, como uma escolha intencional, é representada por uma mulher, profissão típica do imaginário masculino, aqui resignificada quanto ao gênero. 0 agricultor é representado por um homem, mas acima do peso tido como ideal, fato até comum à profissão, enquanto o carpinteiro se aproxima do papel tido como comum ao gênero escolhido. A opção de ilustração do ambientalista foi obtida a partir da necessidade de representação dos movimentos políticos e reivindicatórios de âmbito estudantil.

Durante as escolhas dessa fase do processo, realizamos pesquisas em bancos de imagens na internet, buscando por fotografias que ilustrassem essas profissões nos moldes pensados pela equipe. Notadamente, encontrar imagens que ilustrassem a profissão de mineradora, dentro do enfoque de gênero proposto, foi muito difícil; já para o Ambientalista, buscamos fotos da participação dos estudantes durante os movimentos de ocupação da UFCA ocorridos em 2016. Essas fotos foram enviadas para a equipe de design que, a partir de nossas indicações, criou tais ilustrações.
Estabelecemos, assim, a planta baixa do jogo.

Na interpretação dos signos presentes em nossas escolhas reside nosso interesse de o participante realizar as ações propostas pelo próprio jogo; são pensados como elementos motivadores a partir do conceito de interação lúdica significativa - uma vez que é abordada uma temática social e sustentável. Os participantes têm a possibilidade de imergir no ambiente controlado, onde constroem um conhecimento coletivo através da interação favorecida pelo lúdico, demonstrando seu ponto de vista e aprendendo de forma cooperativa ao captar as impressões dos seus companheiros sobre esses signos e suas interpretações pessoais.

Essa é uma decisão de design de jogo que influencia a forma como serão geridos os processos que o conduzem: metas, regras, feedback e forma de participação. Tomamos como base o questionamento que nos é apresentado por Paulo Freire (1996): “Por que não estabelecer uma necessária 'intimidade' entre os saberes curriculares fundamentais aos alunos e a experiência social que eles têm como indivíduos?" Estando para além das questões de design de jogos, tomamos essas decisões por pensar o ambiente de jogo como uma possibilidade de utilizar conhecimentos já comuns aos jogadores, partindo da ideia de que sua interpretação reside em seu conhecimento prévio. Acreditamos no desejo dos participantes em utilizar, de forma criativa, suas habilidades e competências, que seriam de difícil uso em situações cotidianas do contexto da educação tradicional. Todas as escolhas remetem a isso.

\section{Metas do jogo}

Os objetivos são escolhidos de acordo com o ambiente. Para se jogar esse jogo, os participantes devem colaborar para o desenvolvimento do Vilarejo de Umuechem, assim, tomamos como base o pensamento comum para o objetivo do jogo: a vila é povoada por sapos, entre 
adultos e crianças. No início do jogo, os jogadores têm à disposição três sapos adultos, sendo seu objetivo ter o total de oito sapos adultos. Para atingir esse objetivo, os participantes gerenciam recursos que são coletados pelos seus personagens no jogo e utilizam esses recursos para "transformar" os sapos filhotes em sapos adultos (a aquisição e o uso de recursos serão explicados no ponto de regras).

Temos em mente que o papel da meta é o "resultado específico que os jogadores vão trabalhar para conseguir. Ela foca a atenção e orienta continuamente a participação deles ao longo do jogo" (MCGONIAL, 2012, p. 30). Esta deve estar sempre clara aos jogadores, é o objetivo do jogo. Mesmo não sendo a finalidade ao se aplicar um jogo cooperativo, é importante, pois gera um senso de objetivo.

\section{Regras do jogo}

Regras são as diretrizes norteadoras do jogo, postas para limitar a forma como as atividades deverão ser realizadas. 0 papel das regras é entendido como:

[...] impõem limitações em como os jogadores podem atingir a meta. Removendo ou limitando as maneiras óbvias, as regras estimulam os jogadores a explorarem as possibilidades anteriormente desconhecidas para atingir o objetivo final. Elas liberam a criatividade e estimulam o pensamento estratégico. (MCGONIAL, 2012, p. 31).

Não são as regras, portanto, formas de punir os participantes, mas sim de auxiliá-los nessa jornada em busca da construção e (re) significação de conhecimentos e habilidades, estimulando a criatividade. Agora, veremos as regras ou mecânicas do jogo. ${ }^{7}$

A mecânica central do jogo é o gerenciamento de recursos. Os participantes buscam recursos: madeira, pedra, tijolo, vegetais e peixes que estão espalhados pelo tabuleiro do jogo. Além disso existem dois outros recursos essenciais, educação e saúde, que são conseguidos a partir das ações dos personagens, não estando disponíveis para coleta. Esses recursos servem para que eles possam criar diversas construções na vila e transformar sapos filhotes em sapos adultos. Cada personagem tem características que auxiliam a encontrar esses recursos com maior facilidade, todos dispostos nas fichas de personagens, como vemos na Figura 7.

Figura 7 - Ficha da personagem líder da vila

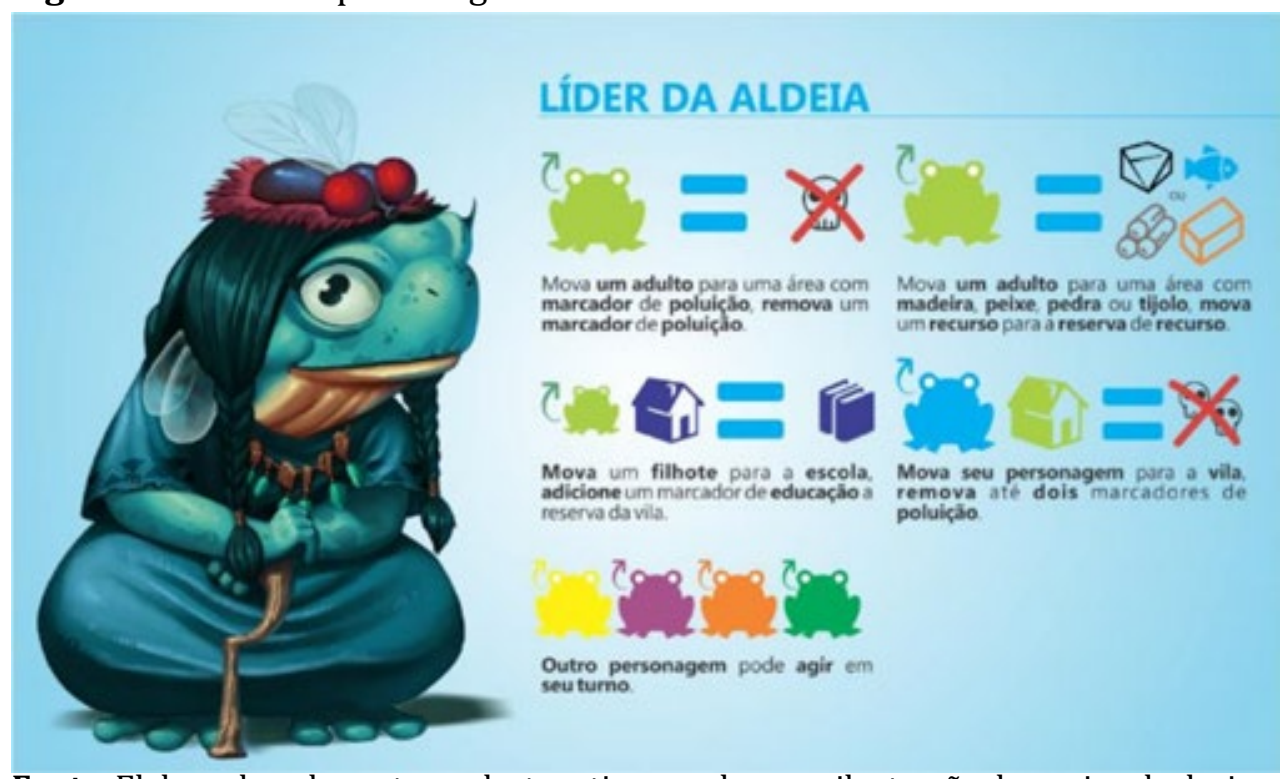

Fonte: Elaborado pelos autores deste artigo com base na ilustração da equipe de design.

7 Regras, mecânicas, regras de jogo e mecânicas de jogo, no escopo deste artigo, são sinônimos para as possibilidades de atuação, dentro do ambiente controlado do jogo, por parte dos participantes. 
Entre as funções da Líder da vila estão: remover marcadores de poluição, movendo um sapo adulto até uma área poluída; mover um sapo adulto para uma área onde tenha pedra, peixe, madeira ou tijolo e coletar esse recurso; mover um sapo filhote até a escola e receber um ponto de educação; mover a personagem para qualquer lugar da vila e remover dois marcadores de poluição; ou estabelecer que outro personagem faça uma ação à sua escolha.

Figura 8 - Ficha da personagem mineradora

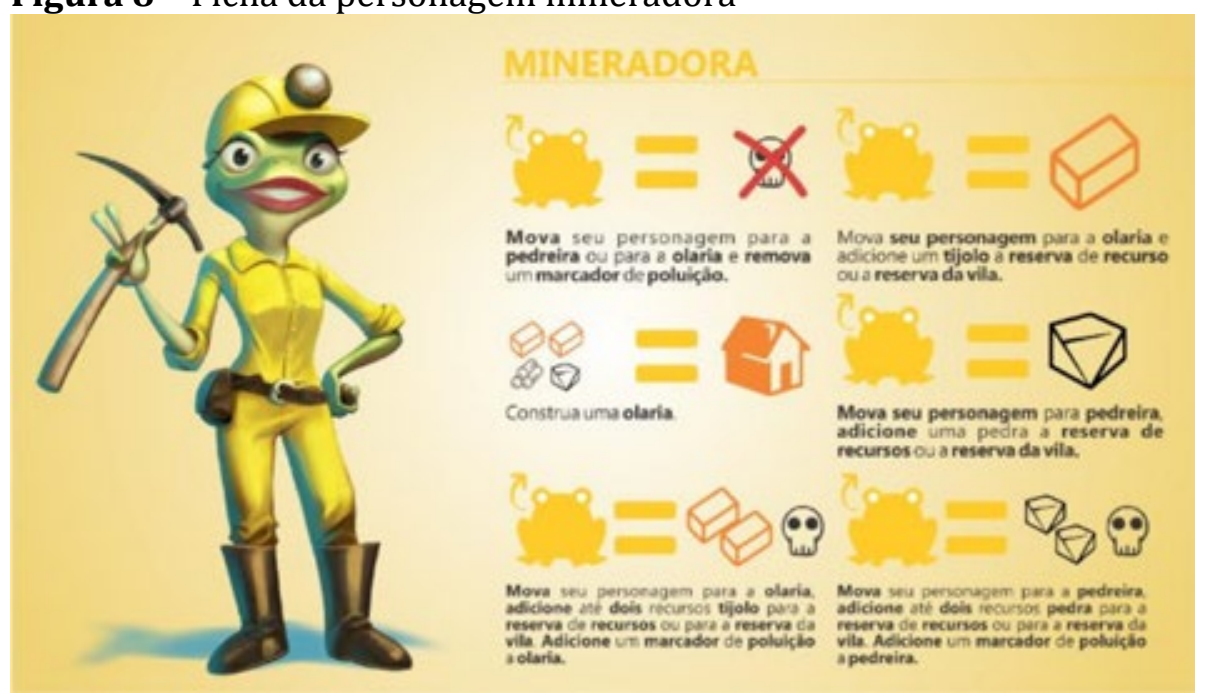

Fonte: Elaborado pelos autores deste artigo com base na ilustração da equipe de design.

As funções da Mineradora são: remover poluição da pedreira, do rio ou da olaria; recolher tijolo na olaria ou pedra na pedreira; remover dois tijolos da olaria, criando um marcador de poluição; remover duas pedras da mina, criando um marcador de poluição; construir uma olaria. 0 jogador pode optar por recolher uma menor quantidade de recursos (pedra e tijolo) sem ocasionar poluição, ou então conseguir o dobro de recursos, ocasionando poluição. Essa escolha de design, também presente nos outros personagens, está ligada ao uso sustentável

Figura 9 - Ficha de personagem do agricultor

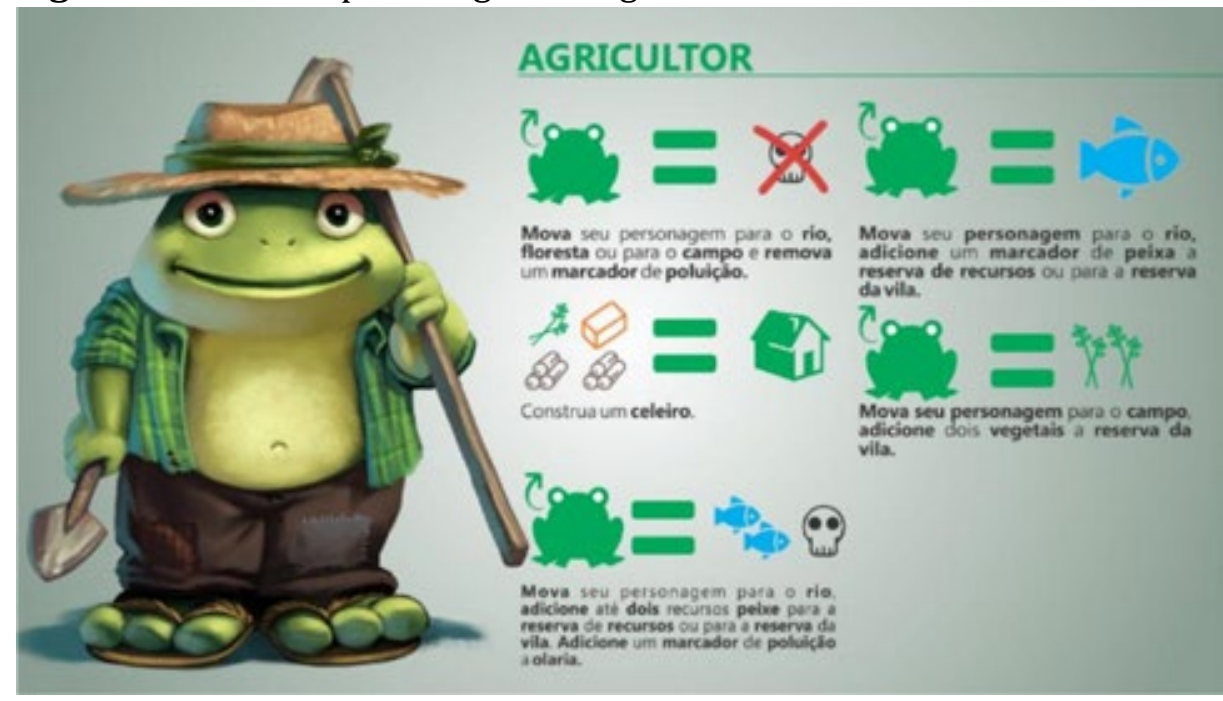

Fonte: Elaborado pelos autores deste artigo com base na ilustração da equipe de design. 
dos bens e serviços que a natureza oferece e à capacidade de resiliência ${ }^{8}$ da natureza. Desta forma, colocamos a escolha na mão do jogador, visando proporcionar discussão com os outros jogadores na tomada de decisão.
As funções do Agricultor no jogo são: remover poluição do rio ou do campo de plantio; pegar um peixe; criar um celeiro; colher dois vegetais; pegar dois peixes, ocasionando poluição.

Figura 10 - Ficha de personagem do carpinteiro

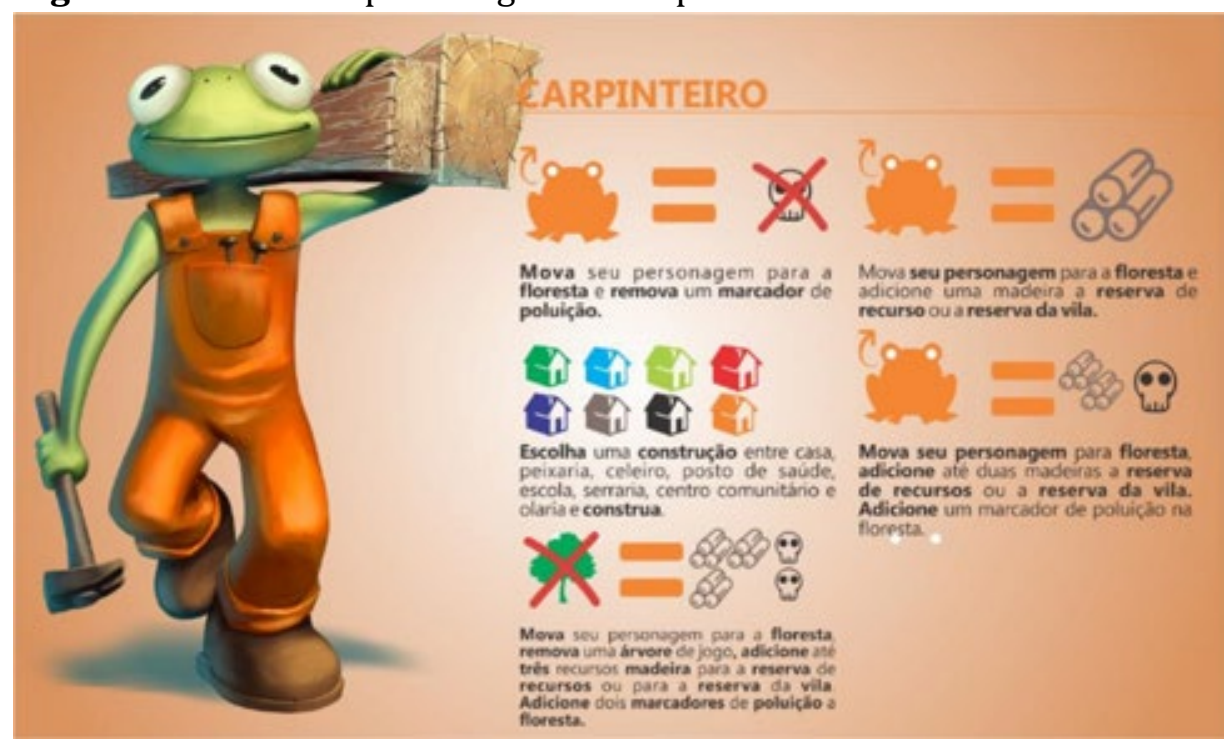

Fonte: Elaborado pelos autores deste artigo com base na ilustração da equipe de design.

As funções do Carpinteiro são: remover poluição da floresta; coletar uma madeira; coletar duas madeiras, deixando um marcador de poluição; derrubar uma árvore, coletar três madeiras, deixando um marcador de poluição; ou criar qualquer uma das construções possíveis no jogo.

Figura 11 - Ficha do personagem ambientalista

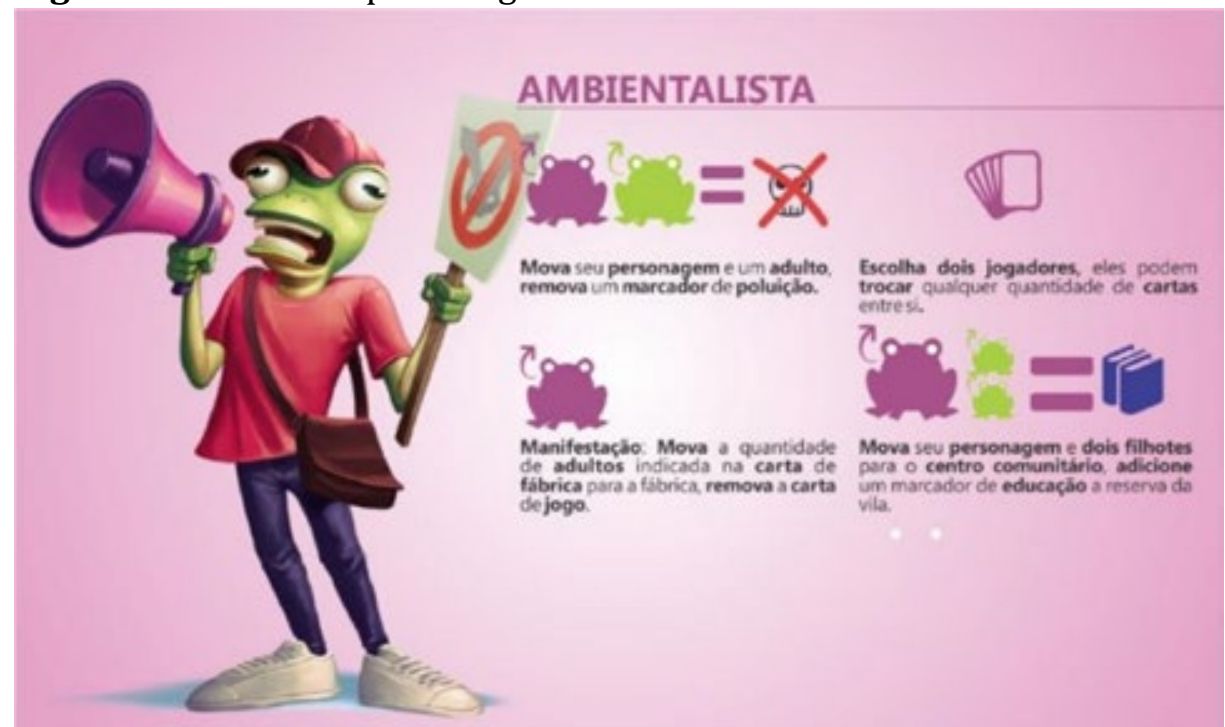

Fonte: Elaborado pelos autores deste artigo com base na ilustração da equipe de design.

8 Entendemos como resiliência "a capacidade de um sistema em manter-se a despeito de um transtorno, sem passar para um estado novo. Também se define como a capacidade do sistema de retornar ao seu estar original” (ALIER, 2015, p. 77). 
O Ambientalista apresenta as seguintes funções no jogo: movendo-o e a outro sapo adulto, eles removem um marcador de poluição; ele pode escolher dois jogadores para trocarem cartas; pode realizar uma manifestação; mover seu personagem e dois sapos filhotes para o centro comunitário e receber um marcador de educação.

Cada jogador, na sua vez, escolhe uma dessas habilidades dos personagens, executa-a e passa a vez para o próximo jogador. Chamamos isso de ação do jogador, e quando todos os jogadores já fizeram sua ação, chamamos isso de rodada. 0 jogo começa sempre pelo Líder da vila e à esquerda deste, em que os jogadores escolhem, por consenso, quem jogará com qual personagem.

Para controlar o fluxo de rodadas do jogo utilizamos um sistema de estações, que representa as quatro estações do ano. Assim que todos os jogadores fizerem uma ação, muda-se automaticamente de estação.

Figura 12 - Diagrama do sistema de estações

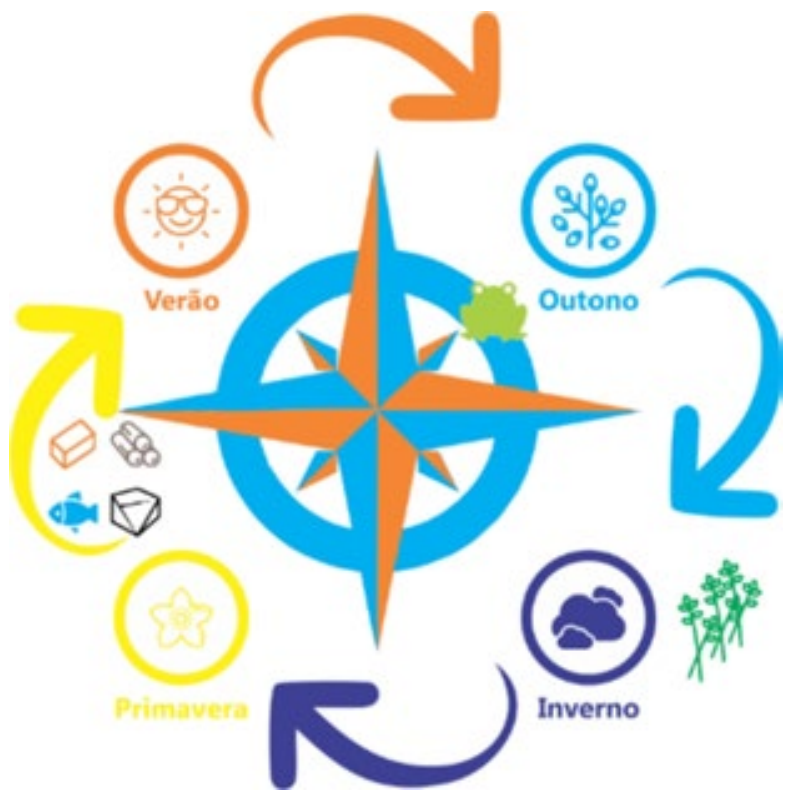

Fonte: Elaborado pelos autores deste artigo.

O jogo se inicia no verão; depois que todos os jogadores fizerem suas ações ele muda para o outono. No inverno todos os recursos de vegetais que estiverem no campo são movidos para "recursos disponíveis na vila", presente no tabuleiro. Na passagem da primavera para o verão, os jogadores têm que decidir em conjunto para escolher cinco recursos que serão movidos do campo "recursos disponíveis" para o campo reserva da vila. Para construir e desenvolver sapos, eles só podem utilizar os recursos presentes no campo "recursos disponíveis na vila".

No jogo, os recursos manipulados são representados por cubos impressos em 3D, que são dispostos nas reservas e gastos pelos jogadores. Um jogador sozinho não pode escolher gastar recursos; isso garante que as ações tomadas sejam consensuais.

Figura 13 - Cubos que representam os recursos: laranja - tijolo, cinza marmorizado - pedras, azul peixes, verde - vegetais, marrom - madeira

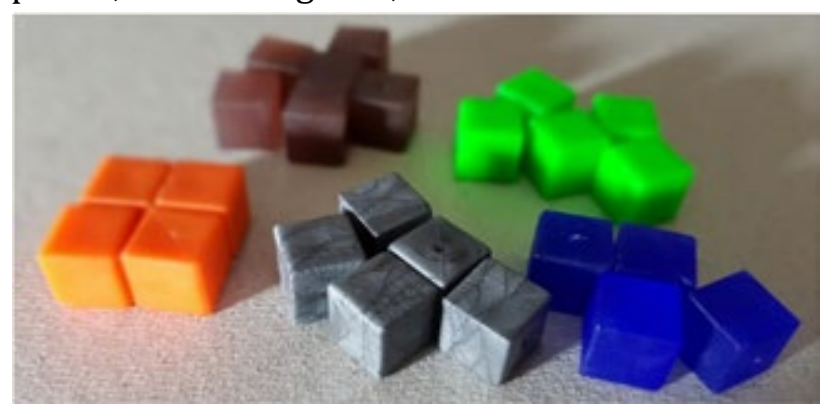

Fonte: Acervo dos autores deste artigo.

Figura 14 - Cubos que representam recursos: vermelho - saúde, azul escuro - educação

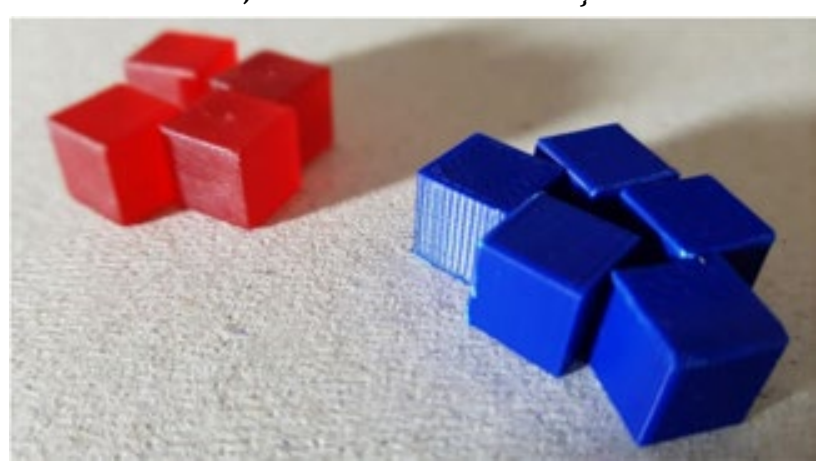

Fonte: Acervo dos autores deste artigo.

A ideia de usar cubos é comum em jogos de tabuleiro, pois eles são ótimos para manipulação, auxiliam os jogadores na contagem de seus recursos e podem ser facilmente organizados e sistematizados. Além dos cubos, criamos uma série de ícones que representam esses recursos, para as cartas e para o tabuleiro. 
Figura 15 - Da esquerda para a direita: saúde, educação, madeira, peixe, tijolo, vegetais e pedra
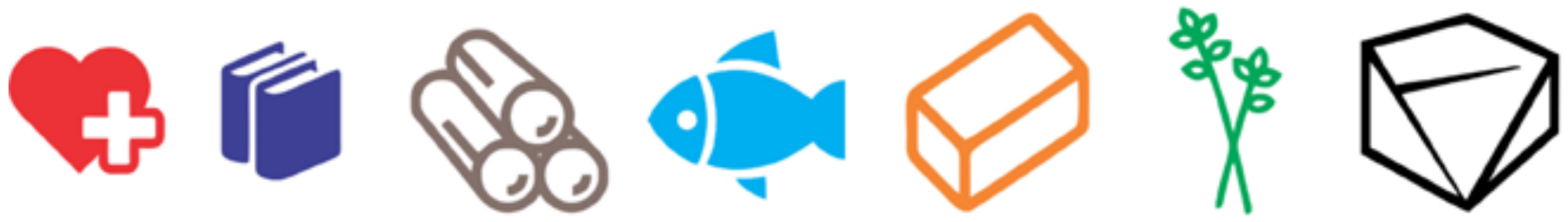

Fonte: Elaborados pelos autores deste artigo.

O uso dos ícones facilita a leitura e a interpretação. Nas fichas de personagens temos alguns destes ícones, bem como nas cartas e no tabuleiro. Partimos do princípio de que eles podem auxiliar os jogadores na com- preensão a fim de acelerar o jogo. Os recursos são utilizados para construir estruturas e desenvolver sapos. Estruturas são possíveis de serem criadas no jogo, como mostra a Figura 16.

Figura 16 - Construções que os jogadores podem fazer no jogo
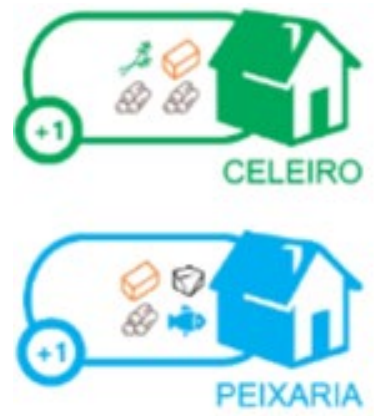
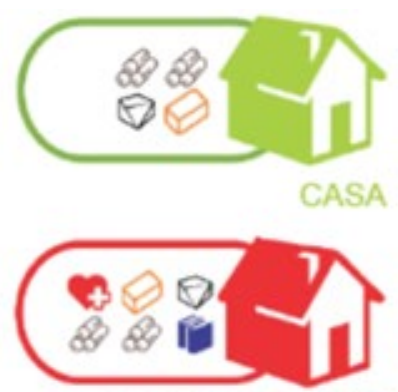

POSTO DE SAÚDE
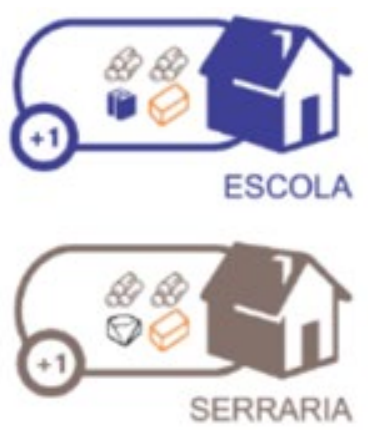
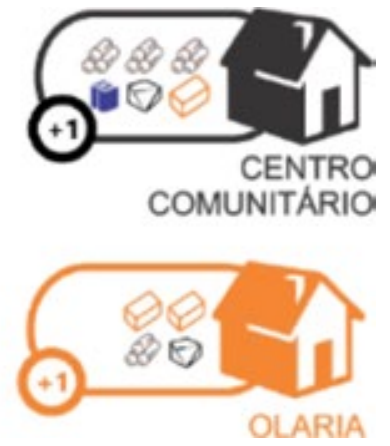

Fonte: Elaborado pelos autores deste artigo.

Cada uma dessas construções traz algumas facilidades para a vila, sendo suas funções: Casa - para cada dois adultos no jogo, deve haver uma casa construída; os jogadores começam com duas casas e precisam, ao menos, construir mais duas para alocarem os oito sapos e assim cumprir o objetivo do jogo; Celeiro - sempre que passar da primavera para o verão, a vila recebe um vegetal adicional; Escola - sempre que passar da primavera para o verão, os jogadores recebem um marcador de educação; a Líder pode enviar as crianças para a escola usando a sua vez para receber um marcador de educação extra; Centro Comunitário - sempre que o ambientalista for realizar uma ação de manifestação, ele conta com um adulto extra; além disso, o ambientalista consegue levar crianças ao centro comunitário e receber um marcador de educação extra; Peixaria - sempre que mudar da primavera para o verão, a vila recebe um peixe extra; Posto de Saúde - a quantidade de sapos adultos nunca pode ser maior que a quantidade de marcadores de saúde; se isso ocorrer, os jogadores perdem sapos até ficarem equiparados; isso pode ser interpretado como a morte dos sapos; para evitá-lo, os jogadores constroem Postos de Saúde e os sapos, ao invés de morrerem, são enviados para lá; Serraria sempre que mudar da primavera para o verão, a vila recebe uma madeira extra; Olaria - sempre que mudar da primavera para o verão, os jogadores recebem um tijolo extra.

No início do jogo, as únicas construções na vila são duas casas. À medida que os jogadores vão escolhendo construir essas estruturas, eles pegam as peças impressas em 3D correspondentes ao tipo de construção e adicionam em um espaço escolhido da vila. Apenas o personagem Carpinteiro tem a habilidade de construir todos os tipos de estruturas disponíveis. 
Figura 17 - De baixo para cima: branca - celeiro, preta - centro comunitário, amarela - serraria, vermelho escuro - olaria, azul claro - peixaria, verde - casas dos sapos, vermelho - posto de saúde, azul escura - escola

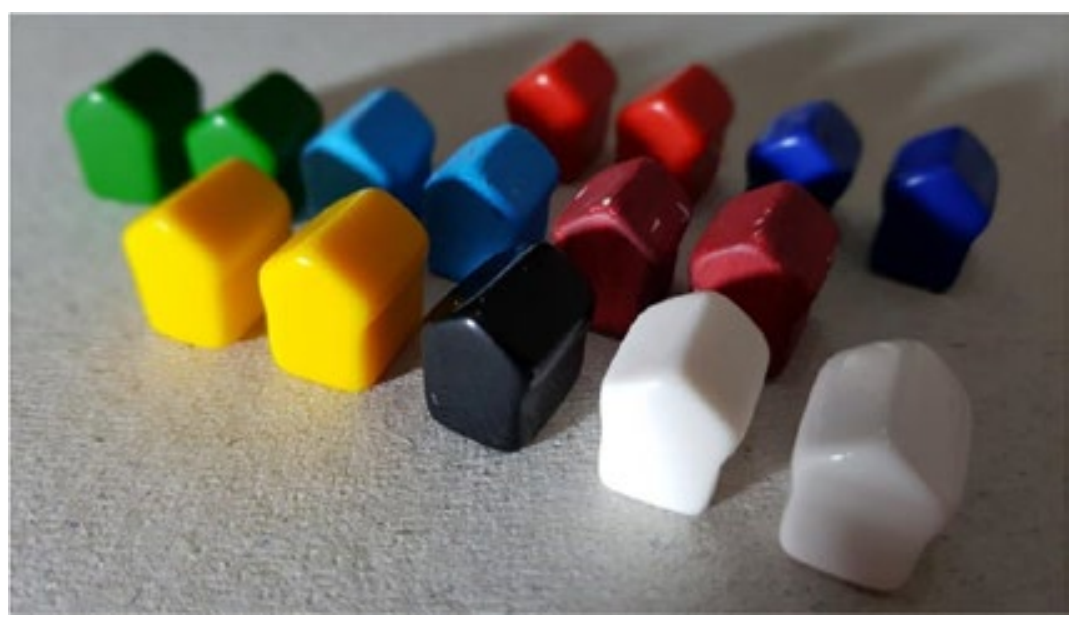

Fonte: Acervo dos autores deste artigo.

Os recursos podem ser adicionados a dois lugares no tabuleiro: um campo nomeado "recursos disponíveis na vila", que podem ser acessados e utilizados durante as ações dos jogadores; e outro campo nomeado "recursos disponíveis" - na passagem da primavera para o verão, os jogadores entram em consenso para mover até cinco recursos desta reserva para a primeira. A ideia é que os recursos disponíveis na vila representam o que está pronto para utilização, enquanto recursos disponíveis é um estoque protegido, que pode ser utilizado pelos habitantes fictícios da vila.

Figura 18 - Campo recursos disponíveis

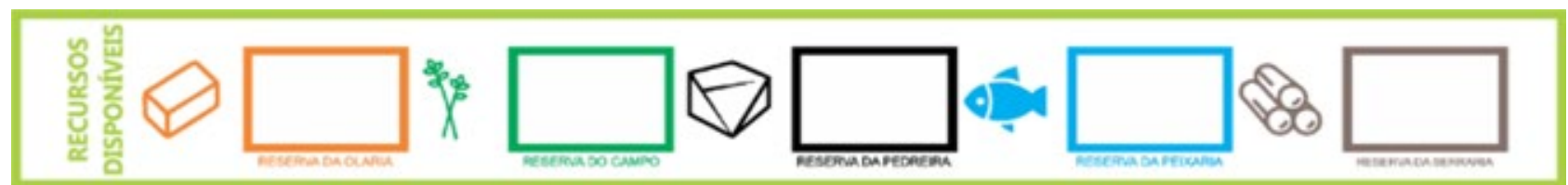

Fonte: Elaborado pelos autores deste artigo.

Figura 19 - Campo recursos disponíveis na vila

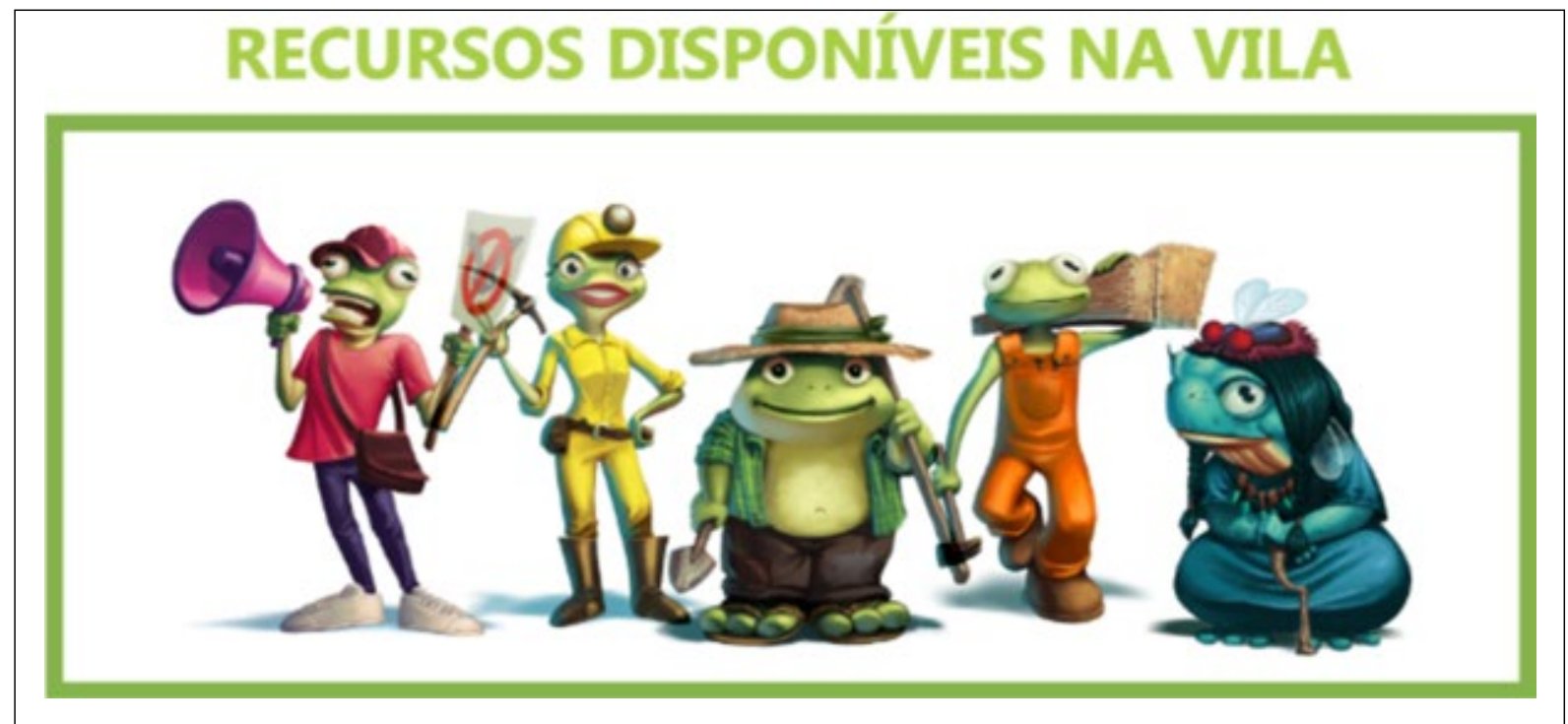

Fonte: Elaborado pelos autores deste artigo. 
Para cumprir o objetivo principal do jogo, os jogadores trocam recursos para transformar sapos filhotes em sapos adultos. Para isso, na vez de jogar de um participante ele deve escolher um sapo filhote, gastar dois marcadores de educação, dois marcadores de saúde, um marcador de peixe e outro marcador de vegetal. Assim que o novo sapo adulto entra em jogo, dois sapos filhotes o acompanham. A ideia é representar que as crianças devem estar bem-educadas, saudáveis e alimentadas para chegar à idade adulta, e apenas os adultos podem trabalhar; os filhotes podem ir para a escola estudar ou ao centro comunitário, brincar e aprender com os outros.

Figura 20 - Ícones apresentados no tabuleiro para lembrar aos jogadores como proceder para criar um sapo adulto

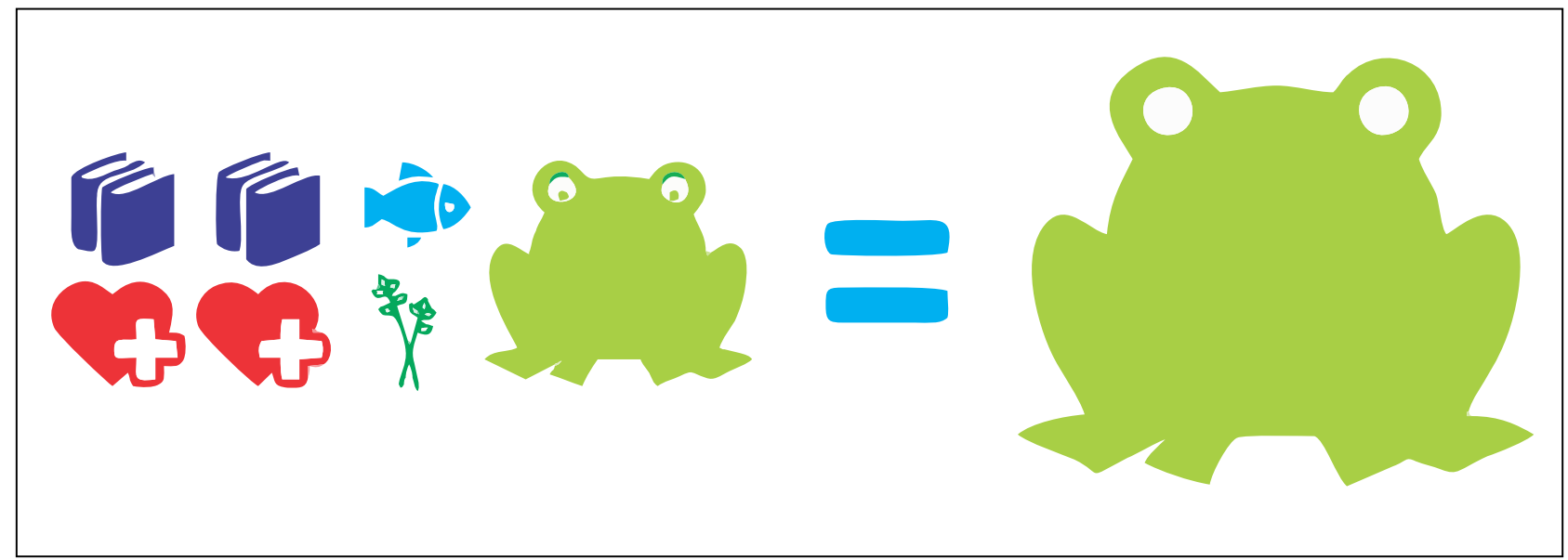

Fonte: Elaborado pelos autores deste artigo.

Criamos ícones para representar os sapos filhotes (um sapinho pequeno) e os sapos adultos (um sapo grande) e, no tabuleiro, estes sapos são representados por peças impressas em 3D.

Figura 21 - No topo, ficha verde utilizada para marcar a passagem das estações; ao lado, peças de sapos adultos; na parte inferior, peças de sapos filhotes

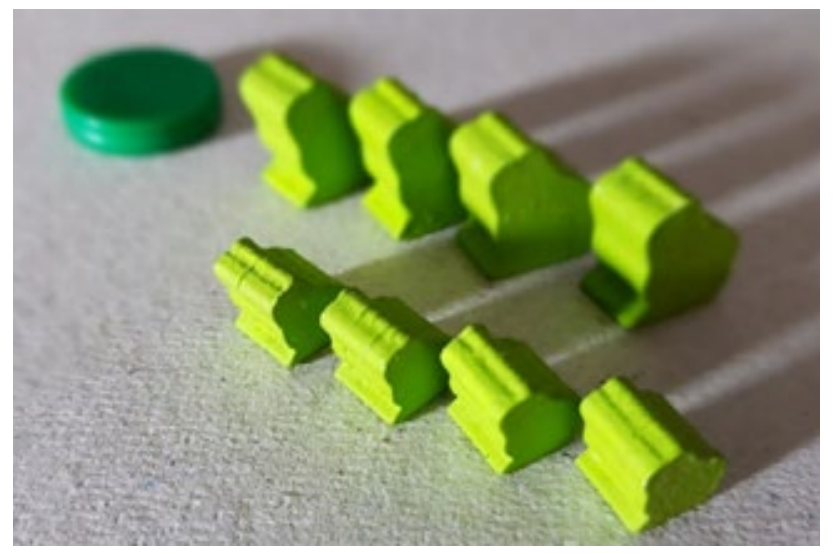

Fonte: Acervo dos autores deste artigo.
Figura 22 - Modelos 3D de sapos adultos e sapos filhotes

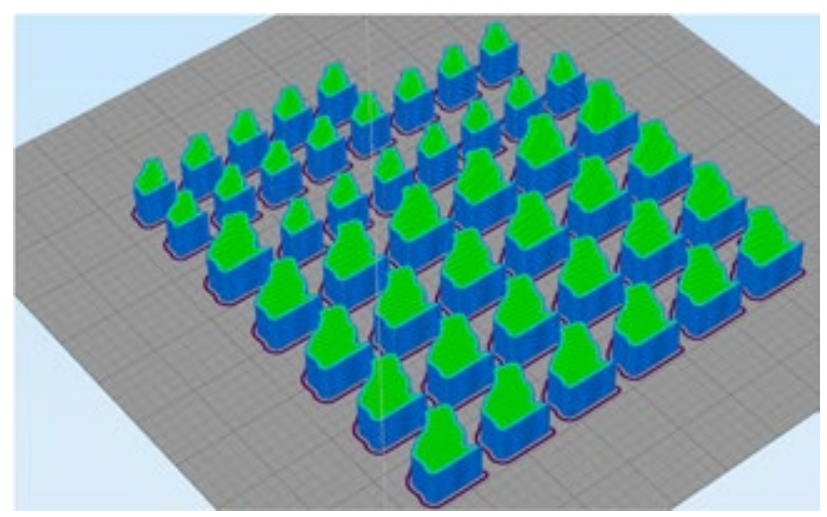

Fonte: Modelo elaborado pela equipe de design.

Todos os elementos apresentados, e alguns elementos restantes, foram inseridos no tabuleiro do jogo, que na sua versão final tem o tamanho de $93 \mathrm{~cm} \mathrm{X} 70 \mathrm{~cm}$, tendo sido impresso em lona vinílica. ${ }^{9}$ Esse tipo de impressão, além de durável, é de fácil transporte e baixo custo, sendo encontrado na maioria das gráficas.

9 Lona vinílica é utilizada para impressão de banners de apresentação de trabalhos científicos. 
Figura 23 - Versão final do tabuleiro do jogo

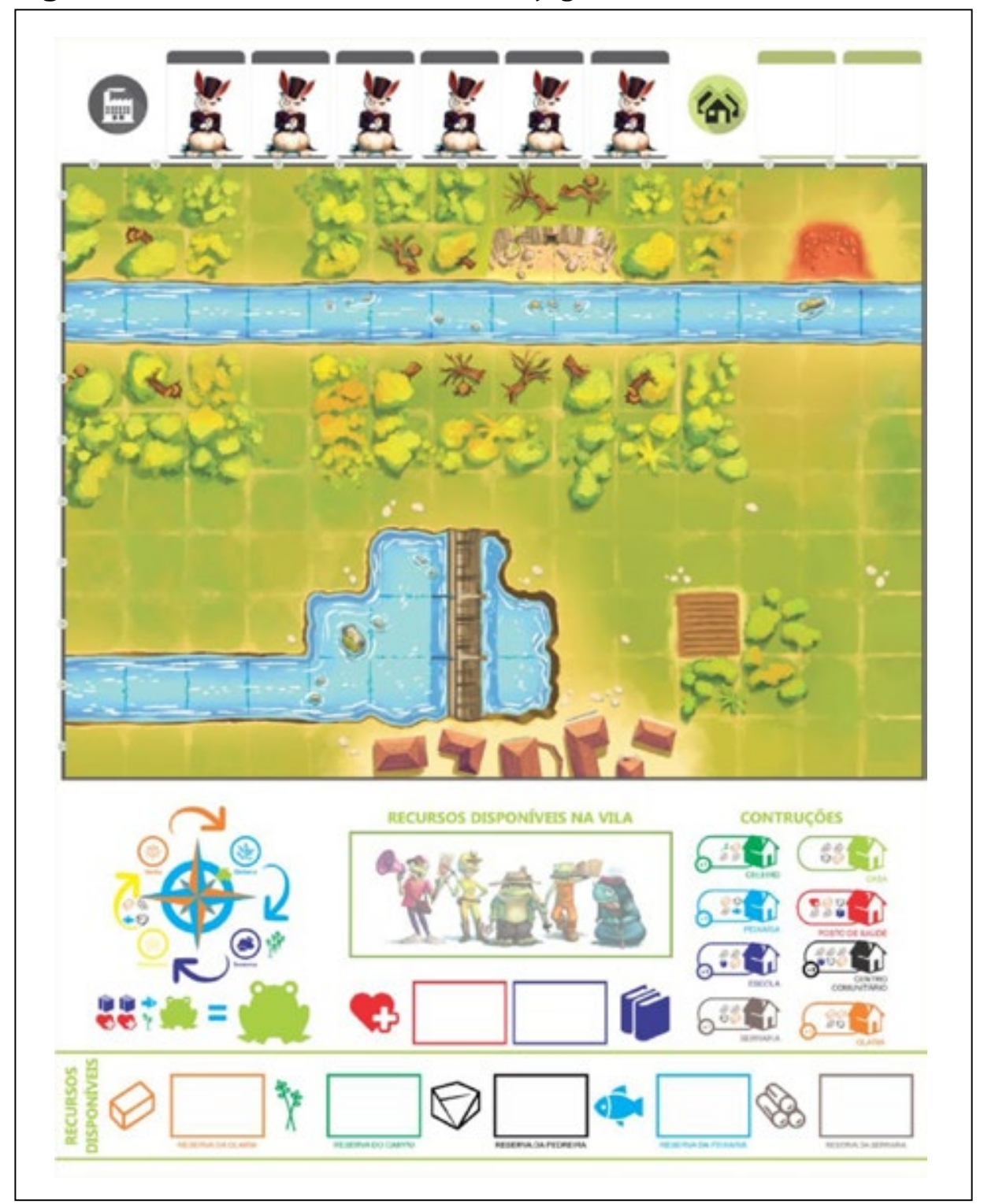

Fonte: Elaborado pela equipe de design, autores deste artigo e equipe criativa.

Note que o local dos marcadores de recursos saúde e educação estão dispostos logo abaixo do campo recursos disponíveis na vila. Este campo também é aberto ao uso, a qualquer momento, pelos jogadores. Todos os recursos e elementos do jogo estão sistematizados no tabuleiro e nas fichas de personagens, o que facilita uma visualização ampla dos elementos do jogo para a tomada de decisão. Os participantes podem manipular os marcadores e miniaturas no tabuleiro, discutir com os outros jogadores possibilidades de curso de ação, demonstrando suas vantagens e desvantagens.

Essas são as regras básicas do jogo. A premissa é simples: gerenciar recursos para desenvolver a vila. No entanto, no decorrer da partida o cenário muda, uma nova dinâmica de jogo é inserida. Logo após a passagem do primeiro ano, quando eles retornam ao verão, é inserida no jogo a Fábrica.

Visando manter a narrativa apresentada em que baseia a planta baixa do jogo, uma nova mecânica é inserida: a Fábrica é um elemento que traz situações-problema para o jogo e exige dos participantes maior esforço para superar os desafios postos até então. A Fábrica representa aqui a causa do conflito ambiental; esta mecânica vai coletar e destruir recursos, inserir a mecânica de poluição e de situações-problema no jogo. 
Figura 24 - Miniaturas representando fábricas

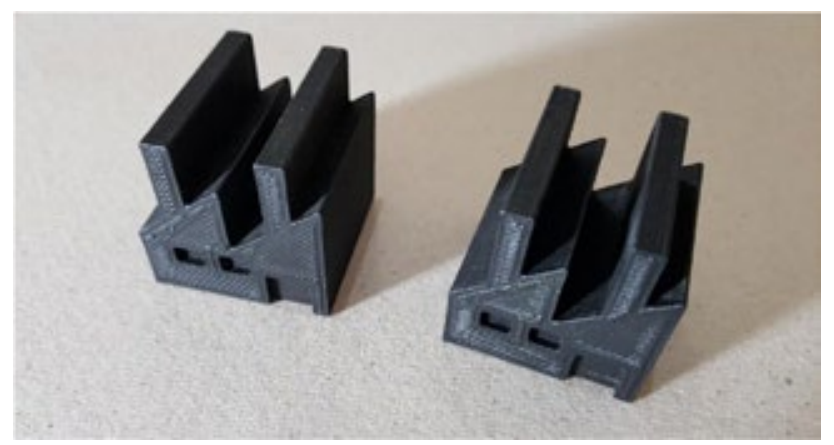

Fonte: Acervo dos autores deste artigo.

Logo que a fábrica é colocada no mapa de jogo, cada quadrado ao lado da fábrica, em todas as direções, recebe um marcador de poluição. Como regra, não se pode coletar recursos de locais com marcadores de poluição até que estes sejam removidos. Os marcadores de poluição são representados por cubos pretos e cubos cinzas (usados nos espaços com água). Além disso, se um personagem e/ou trabalhador estiver posicionado em um local que recebe um marcador de poluição, os jogadores perdem aquela quantidade de saúde; no entanto, para cada marcador de poluição removido, eles recebem um marcador de saúde.

Figura 25 - À esquerda, marcadores de poluição para áreas terrestres do mapa; à direita, marcadores de poluição utilizados nos rios

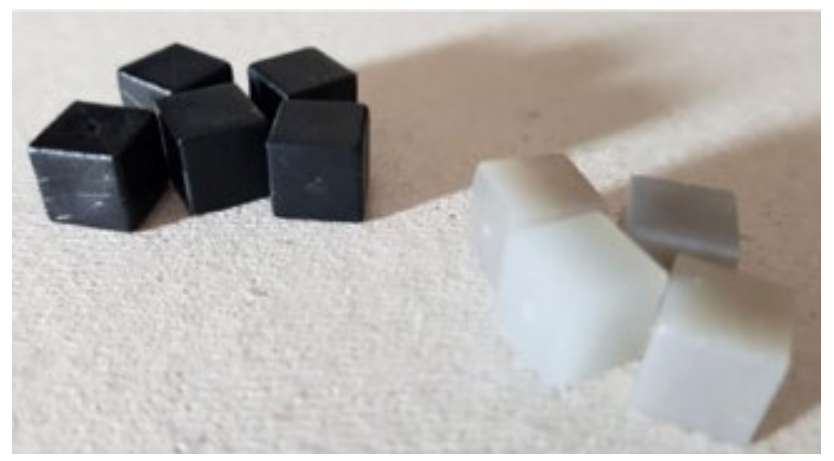

Fonte: Acervo dos autores deste artigo.

A ideia dessa mecânica do jogo parte do pressuposto de que poluição é nociva à saúde, portanto, quando uma miniatura que representa alguém "vivo" está no espaço poluído, isso lhe custa saúde. 0 contrário, trabalhar para garantir a remoção dessa poluição, faz com que o local se torne mais aprazível, possibilitando um aumento da qualidade de "vida" e, portanto, melhorando a saúde.

Essa mecânica insere mais uma dificuldade: não basta agora que os jogadores coletem apenas os recursos. Esse não é um jogo focado em sistematização, como um jogo cooperativo. 0 trabalho em conjunto deve ser a ferramenta ótima para a resolução de situações-problema (ALMEIDA, 2011; ALMEIDA, 2010).

A Fábrica representa o conflito, ela dispõe os desafios do jogo. Os jogadores jogam uns com os outros, contra a fábrica, para atingirem o objetivo geral do jogo. Desta forma, a fábrica representa o conflito e, como tal, cabe uma representação, através da ilustração que facilita a visualização dos envolvidos dentro do universo imaginário situacional.

Continuando a ideia de utilizar elementos antropomórficos nas ilustrações, escolhemos a figura de um coelho, inspirada precisamente no personagem Conde Olaf, da série de livros infanto-juvenis Desventuras em Série, de Daniel Handler. Esse personagem é o arquétipo da avareza, dentro do contexto literário, tendo sido adaptado em filmes e séries. A representação que Daniel Handler fez ao criar o personagem é idêntica à que propomos, aí reside nossa escolha.

Figura 26 - Ilustração do personagem que representa o dono da fábrica

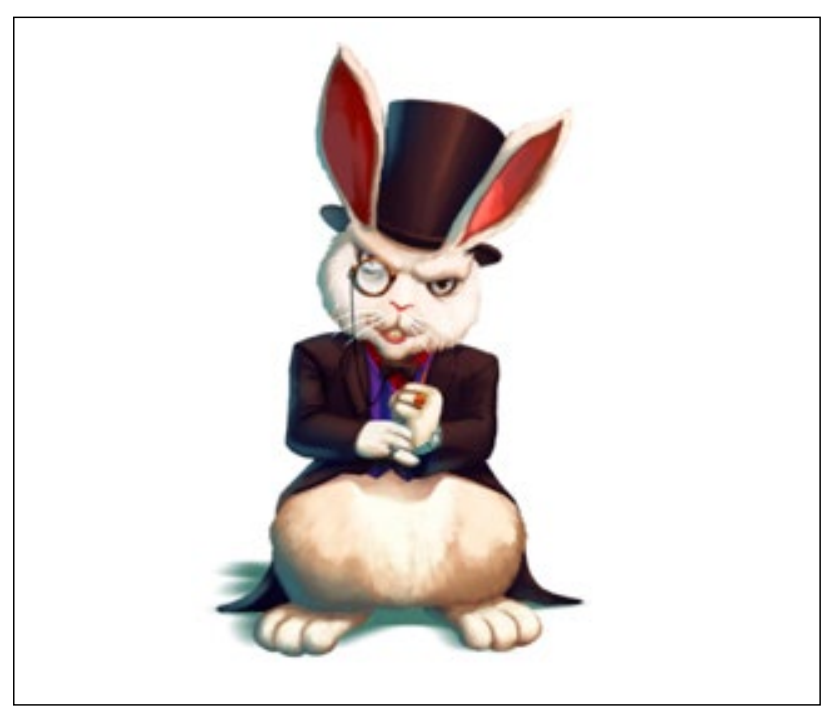

Fonte: Ilustração criada pela equipe de design com base nas opções fornecidas pela equipe criativa. 
A ideia não foi apenas de personificar um vilão para o jogo; ela corrobora dentro de símbolos e signos que representam a ganância e a avareza ao representar a opulência através de bens materiais. 0 personagem ilustrado não representa uma profissão, como os anteriores, mas, sim, posse, a propriedade privada e o controle dos meios de produção. A fábrica representa os desafios e seu dono é quem representa a ordem para que as ações da fábrica ocorram.

Para que tais situações-problema apareçam constantemente no jogo, criamos um sistema de cartas com duas pilhas: a pilha dos jogadores e a pilha da fábrica. A pilha da fábrica apresenta, aleatoriamente, as situações-problema, enquanto a pilha dos jogadores apresenta algumas bonificações que possam ser utilizadas. No total temos 54 cartas que podem auxiliar os jogadores e 36 cartas de problemas da fábrica.

Entre as cartas de fábrica, os desafios são divididos em graus de dificuldade discutidos e definidos no processo de game design. São ao todo quatro cartas com situações muito difíceis, vinte cartas com problemas de média complexidade e doze cartas com problemas de baixa complexidade. Este número foi calculado estatisticamente (CASTANHEIRA, 2012), visando a uma probabilidade equilibrada de eventos $\mathrm{P}(A)$, para garantir a existência de desafios postos na mesa, de variada complexidade. As cartas médias e fáceis são embaralhadas e divididas em quatro montes; a cada um dos montes é acrescida, separadamente, uma carta difícil. Existe a probabilidade do surgimento de uma situação de alta complexidade de 11,11\% a cada jogada, nas 9 primeiras ações da fábrica, sendo a maior possibilidade de cartas de dificuldade média $(55,55 \%)$ e, em seguida, de cartas fáceis $(33,33 \%)$. Sempre temos em mente, durante todo o processo criativo, que o objetivo não é atrapalhar os participantes, mas ocasionar desafios.

Outro sentido proposto por essa opção de design é o de manter a aleatoriedade dos desafios, para que cada partida tenha a possibilidade de ser um novo jogo, garantindo sua rejogabilidade, ${ }^{10}$ tornando-o mais atrativo aos participantes.

Figura 27 - No alto, em verde, o verso das cartas; na parte de baixo, as cartas de fábrica, com seu conteúdo

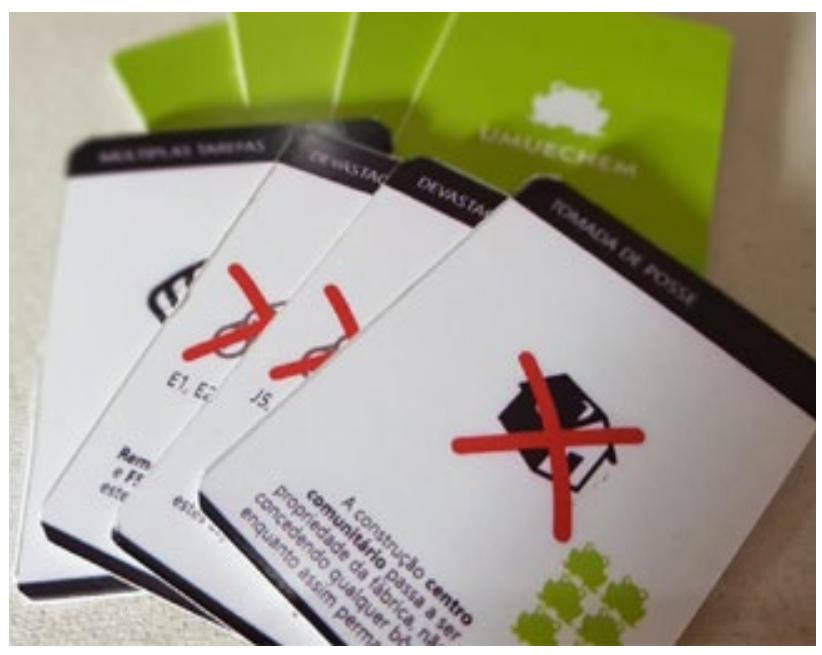

Fonte: Acervo dos autores deste artigo.

As cartas de fábrica possuem um título, que representa o desafio; uma iconografia, que ajuda os participantes a compreenderem o conteúdo deste desafio; um texto explicativo, que insere suas regras específicas; e podem conter elementos para uma manifestação, efetuada pelo personagem ambientalista, para remover essa carta de jogo. Existem duas mecânicas para essas cartas: algumas surtem seu efeito e já saem de jogo e outras requerem uma manifestação para serem resolvidas/removidas. Se os jogadores conseguirem efetuar a manifestação com sucesso, a carta e seus efeitos são removidos de jogo e eles recebem um marcador de recurso extra (à sua escolha, dentre os recursos apresentados no jogo).

No exemplo de carta de fábrica, temos o título - intervenção estatal; um ícone - um sapo cruzado com um "X"; uma ilustração, que representa o dono da fábrica; um texto, que explica o que a carta faz; e ícones de sapos adultos, que representam quantos sapos são necessários para remover esta carta do jogo a partir de uma manifestação.

10 Rejogabilidade é uma preocupação de design que diz respeito a constituir elementos que causam diferencial a cada partida, para que cada vez que o jogo for jogado pelo mesmo grupo possa ser uma nova experiência. 
Figura 28 - Descritivo dos elementos de uma carta de fábrica

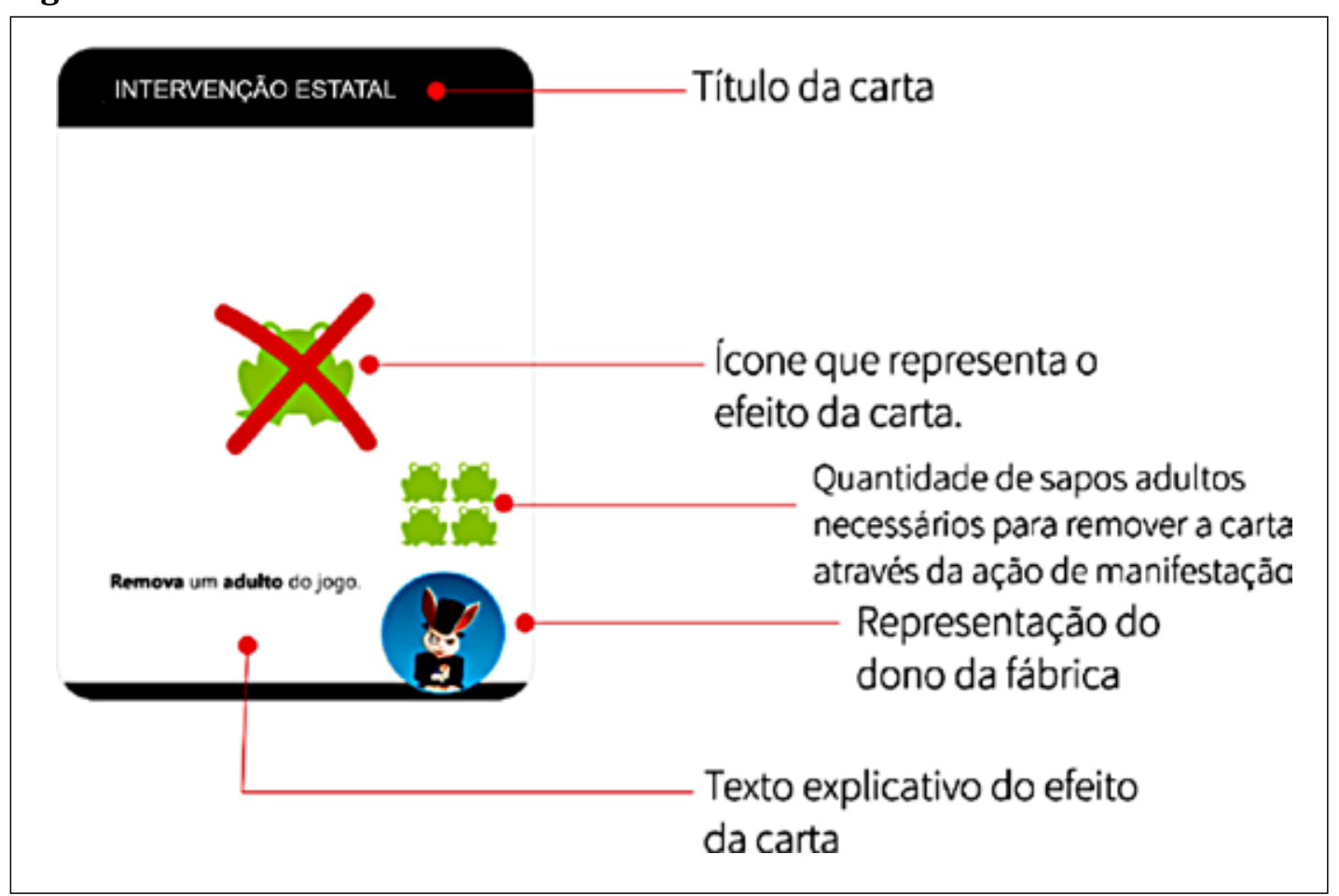

Fonte: Elaborado pelos autores deste artigo.

Na história dos povos Ogoni, dentro do conflito simulado nesse jogo, o Estado interveio com a prisão de populares; é isso que essa carta representa no jogo. Quando esta carta aparece, um sapo adulto é removido de jogo. Após a manifestação efetuada com sucesso, o sapo retorna ao jogo; essa é a ideia que esta carta específica simula.

Dentre as cartas de fábrica, as seguintes situações são simuladas, buscando maior verossimilhança: Devastação - uma quantidade de árvores é removida de jogo imediatamente, colocando marcadores de poluição em seu lugar; Tomada de posse - uma construção criada pelos jogadores e todos os recursos referentes a esta que estejam na reserva disponível na vila, são tomados pela fábrica; Poluição - gases tóxicos espalham marcadores de poluição em locais específicos; Estrada para a pedreira - é construída uma estrada entre a fábrica e a pedreira, derrubando as árvores no caminho e inserindo, em seu lugar, marcadores de poluição; Vapores tóxicos - coloca marcadores de poluição ao redor da fábrica a cada rodada; Inundação - a fábrica gera tanta degradação que afeta a barragem do lago próxima à cidade. Se os personagens dos jogadores não intervirem, a barragem vai ser destruída e inundar a cidade; Intervenção estatal - remove sapos adultos do jogo; Despejo tóxico - são lançados despejos tóxicos nos rios, ocasionando poluição; e Múltiplas tarefas - essa carta é removida de jogo, logo em seguida duas novas cartas de fábrica são colocadas em jogo.

A ideia das cartas para os jogadores, por sua vez, decorre de ofertar outras habilidades para seus personagens, também aumentando as possibilidades de jogo e ações que podem ser utilizadas através de um sistema aleatório. São 54 cartas para os jogadores. No início do jogo, embaralhamos todas as cartas e cada jogador pega duas cartas; na sua vez, ele pode fazer uma das ações propostas nas fichas de personagem, usar uma carta de jogador ou trocar uma carta com outro jogador. Nesse cenário, os jogadores interagem para trocar cartas entre si, já que são estabelecidas duas categorias de cartas: as genéricas, em verde claro, que servem para os jogadores poderem utilizar os sapos adultos para coletar recursos que normalmente seus 
personagens não poderiam ou remover poluição; e as cartas coloridas, que adicionam novas habilidades específicas a seus personagens naquela ação.

Figura 29 - À esquerda, parte traseira das cartas de ação; à direita, algumas das cartas de personagem

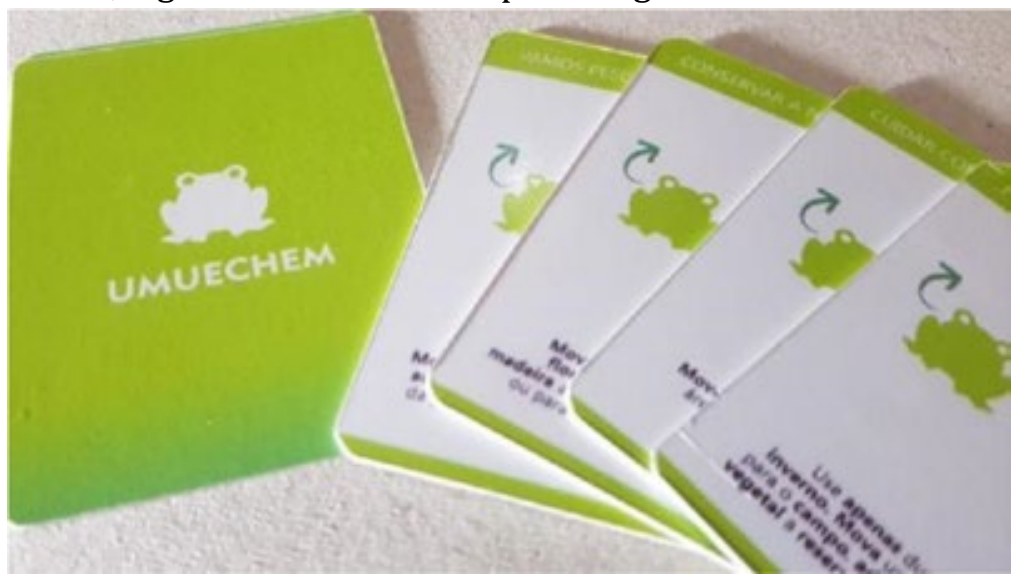

Fonte: Acervo dos autores deste artigo.

Das 54 cartas para os jogadores, temos seis da cor azul, que só podem ser utilizadas pelo Líder da vila; seis verde escuro, que só podem ser utilizadas pelo Agricultor; seis amarelas, que só podem ser utilizadas pela Mineradora; seis roxas, que só podem ser utilizadas pelo
Ambientalista; e seis laranjas, que só podem ser utilizadas pelo Carpinteiro. As cartas específicas para a profissão somam um total de 30 cartas, acrescidas de mais 24 cartas verdeclaro, que qualquer jogador, na sua vez, pode utilizar.

Figura 30 - Cartas de personagem recebem as cores dos personagens em suas bordas e uma ilustração dele

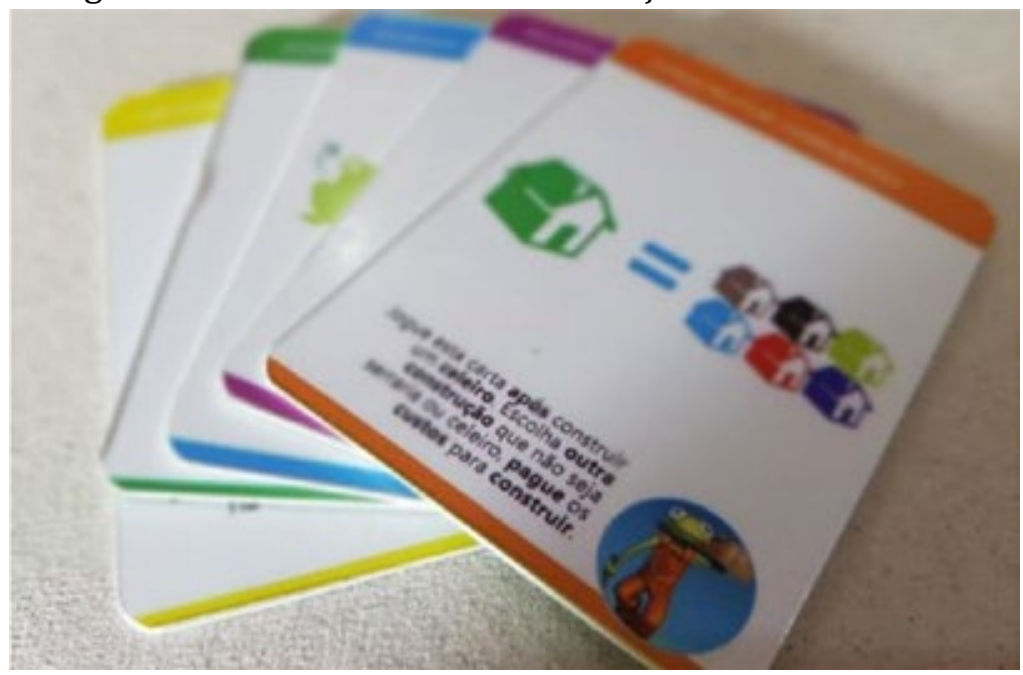

Fonte: Acervo dos autores deste artigo.

O cálculo probabilístico (CASTANHEIRA, 2012) utilizado para a geração dessa quantidade de cartas foi estabelecido a partir da ideia de que devem ser mais raras as oportunidades de encontrar aleatoriamente cartas específicas com habilidades para os personagens. Assim, a chance de se conseguir uma carta específica é muito baixa $(1,85 \%)$, mas a chance de vir uma carta que seja específica para outro personagem é mais alta (55,55\%), ou mesmo se de retirar uma carta que sirva a qualquer personagem $(44,44 \%)$. 
A aleatoriedade não é escolhida por acaso; a ideia é maximizar as interações entre os jogadores, para que eles possam criar estratégias para o uso de cartas, realizar ações diferenciadas combinando essas trocas, chegar a um consenso sobre seu uso ou desuso. Elas são outro tipo de recurso que não pode ser controlado, de forma previsível, e são pensadas a partir de possibilidades que esses personagens poderiam ter no seu mundo ficcional.

Figura 31 - Modelo explicativo de carta genérica de ação

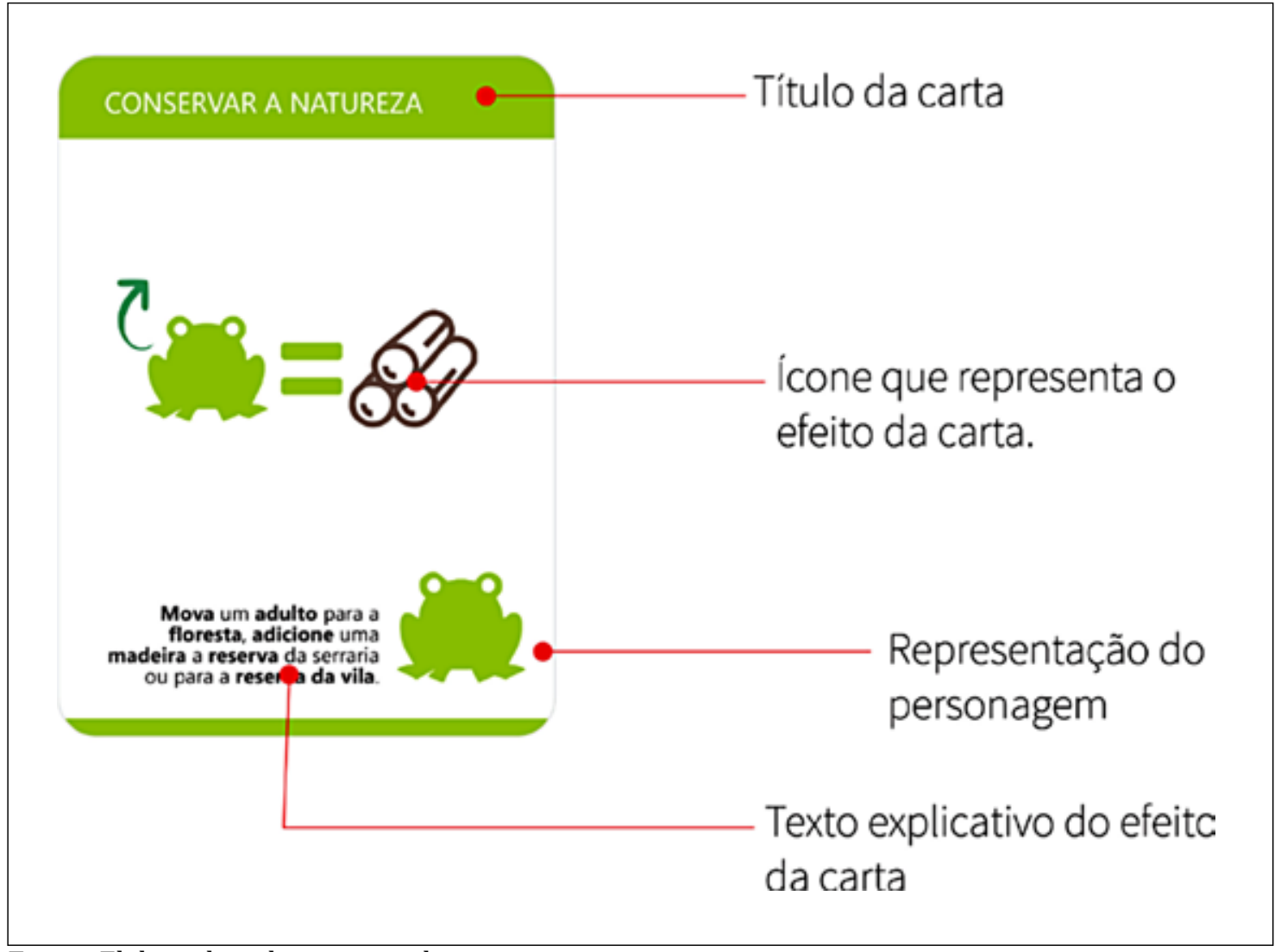

Fonte: Elaborado pelos autores deste artigo.

Para as cartas genéricas temos a cor verdeclaro. No topo, seu título remete à situação da ação realizada por um sapo adulto; no centro, a iconografia, neste caso temos o desenho do ícone de um sapo adulto, uma seta que indica movimento, o sinal de igual, que indica que será o resultado da ação, e o ícone do recurso madeira como resultado. Logo abaixo está o texto explicativo, contendo o efeito da carta e o ícone que indica que é uma carta para usar com sapos adultos.

Entre as cartas de ação genéricas temos as seguintes possibilidades: Cuidar da natureza leva um sapo adulto a remover um marcador de poluição de qualquer lugar; Mão na massa - um sapo adulto é movido até a olaria para pegar um marcador do recurso tijolo; Trabalho árduo - um sapo adulto é movido até a mina para pegar um marcador do recurso pedra; Hora da colheita - um sapo adulto é movido até o campo para pegar um marcador do recurso vegetal; Vamos pescar - um sapo adulto é movido até o rio para pegar um marcador do recurso peixe; e Conservar a natureza - um sapo adulto é movido até a floresta para pegar um marcador do recurso madeira. Essas cartas podem ser interpretadas pelos jogadores como ações que os outros sapos, não controlados pelos jogadores, realizam para colaborar com o desenvolvimento da vila.

Para as cartas de ação, específicas dos personagens, temos os mesmos elementos utilizados, no entanto, precede uma dinâmica diferente de troca e interação entre os próprios jogadores. 
Figura 32 - Carta específica do personagem agricultor explicada

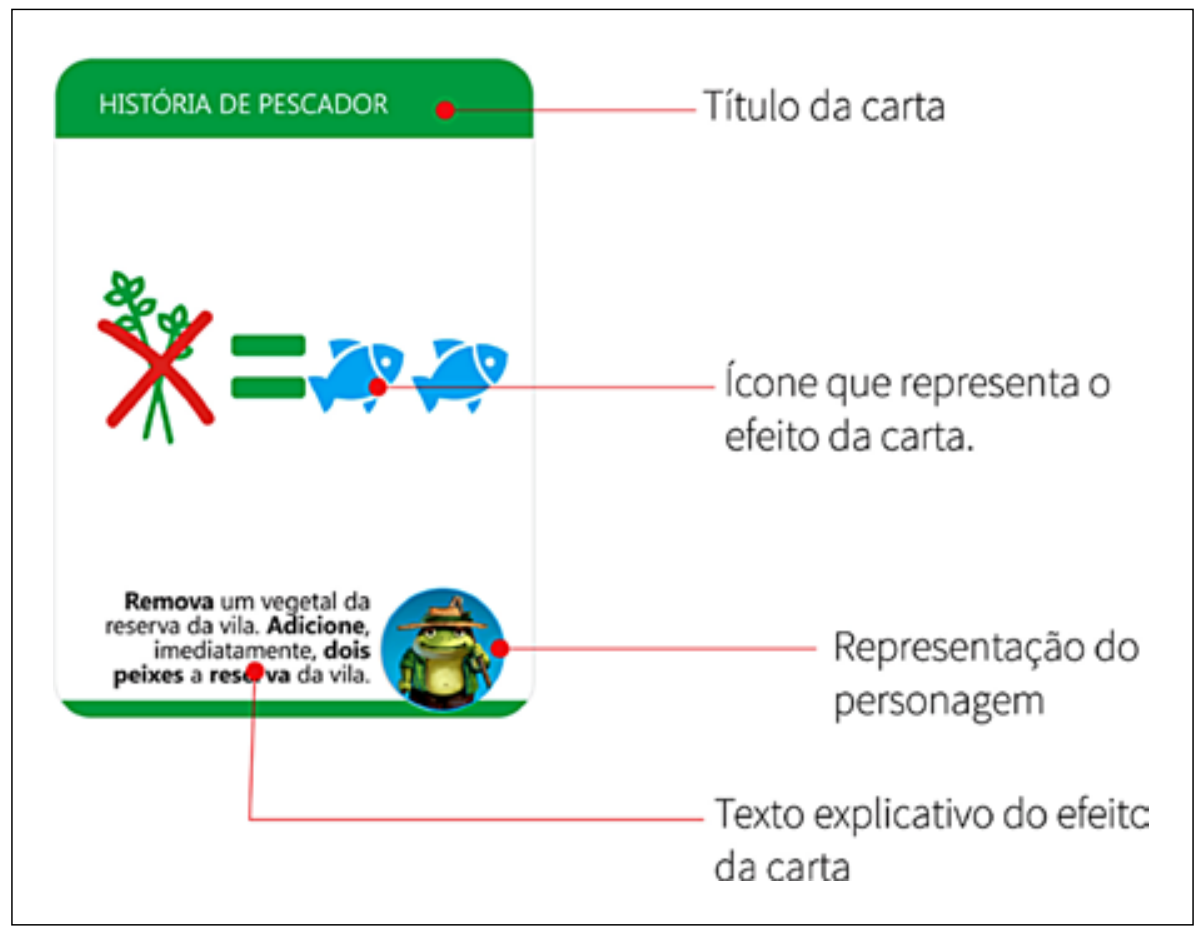

Fonte: Elaborado pelos autores deste artigo.

A carta História de pescador é específica do personagem agricultor, somente o jogador que controla esse personagem pode utilizar. Ela está em verde-escuro, com o título que remete a uma das possibilidades de interpretação; abaixo temos a iconografia que indica um vegetal sendo removido do jogo, o sinal de igual, que simboliza o resultado, e dois peixes como recompensa; logo abaixo temos o texto explicativo da carta e a representação do personagem.

Todos as cartas foram impressas no mesmo formato, tamanho $6,4 \mathrm{~cm} \mathrm{X} \mathrm{8,8} \mathrm{cm,} \mathrm{coloridas,}$ em adesivo plástico brilhante, fixo em acrílico de $2 \mathrm{~mm}$, frente e verso. Um dos lados contém a carta em si e o outro lado contém as cores escolhidas para o jogo, um dégradé de verde -escuro a verde-claro, o logotipo do jogo, um sapo adulto e o nome do jogo, que batizamos de Umuechem.

Por fim, dentro das metas do jogo declaramos o objetivo geral. No entanto, três condições podem fazer com que os jogadores percam o jogo automaticamente: no caso em que todas as árvores do tabuleiro sejam removidas, ou todas as cartas de Fábrica sejam utilizadas, ou os jogadores tenha zero sapos adultos.

\section{Sistema de feedback}

Feedback apresenta as respostas do jogo às ações dos jogadores. Durante o jogo, a cada recurso coletado, ação realizada e tomada de decisão estão explícitos fatores determinantes para que os jogadores alcancem a vitória. Esse sistema de feedback contínuo possibilita um acompanhamento do progresso da atividade por parte dos jogadores, que irão saber o quanto eles estão próximos ou distantes da vitória no jogo (MCGONIAL, 2012). 0 feedback contínuo é importante, pois pode mudar a estratégia dos jogadores de acordo com os novos desafios que vão sendo inseridos.

\section{A participação voluntária}

Uma condição para participar da aplicação do jogo está em aceitar as metas, o sistema de regras e a forma como o feedback será realizado, pois "isso estabelece uma base comum para as múltiplas pessoas jogarem o mesmo jogo" (MCGONIAL, 2012, p. 31), garantindo-lhes a liberdade para entrar e sair do jogo a hora que desejarem, assegurando aos participantes o princípio voluntário de participar. 
Por meio da participação voluntária, construímos um sentimento democrático entre os participantes, que unem forças para resolver situações propostas pelo jogo. No entanto, compreendemos que a participação nesse jogo coaduna com a discussão da aprendizagem cooperativa. Partimos do princípio de que, para a tomada de decisão, os participantes terão dúvidas, necessitarão mediar conflitos, muitas vezes não vão concordar com o rumo das ações propostas; é eminente a contradição neste caso, portanto esse jogo tem características colaborativas (BRUFFEE, 1995). Sendo assim, entendemos que existe a iminência do conflito entre os participantes, mesmo tendo objetivos comuns, mas estes podem ser atingidos de forma diferenciada.

Dessa forma, tal qual as questões postas na discussão sobre aprendizagem cooperativa e colaborativa, tais diferenças assumem que, em nosso processo criativo, esse é um jogo também colaborativo (BRUFFEE, 1995).

\section{Playtest}

Com o objetivo de testar o jogo, para possíveis correções de rumo e adaptações necessárias ao cumprimento dos pontos expostos, realizamos oito partidas de teste, com um total de 20 participantes convidados. 0 intuito destas partidas foi o de testar todos os sistemas de regras aqui expostos, realizar alterações, fazer novos testes, realizar novas alterações, e assim por diante. Esse é um processo necessário no game design: com o primeiro escopo do jogo em mãos, aplicamos o jogo em sua versão inicial.

Observamos se as regras são conflituosas, se as metas são de fácil ou difícil acesso pelos jogadores, se o sistema de feedback os mantém motivados, se e como os jogadores estão se divertindo e participando.

Após avaliarmos o primeiro escopo, o jogo foi completamente revisado. Tomando como base os dados da primeira aplicação, novas mecânicas foram adicionadas e outras retiradas, e novos testes foram feitos de forma a gerar novas avaliações e revisões. Esta fase do ciclo criativo de jogos: teste, avaliação da aplicação do teste e revisão das metas, regras e feedback consome o maior tempo de produção, sendo a parte mais importante e só culminando no lançamento do jogo quando o grupo sentir que os objetivos dele são plenamente alcançáveis pelos participantes (ANTUNES et al., 2018).

Bons jogos são criados por meio de testes, o chamado playtest. Este momento é extremamente necessário, pois alerta a equipe de produção criativa sobre problemas que podem ser resolvidos, verificando se o jogo fomenta a experiência para a qual foi concebido (SCHELL, 2011).

Figura 33 - Momento do playtest de Umuechem realizado na UFCA, com membros e colaboradores do LIJC

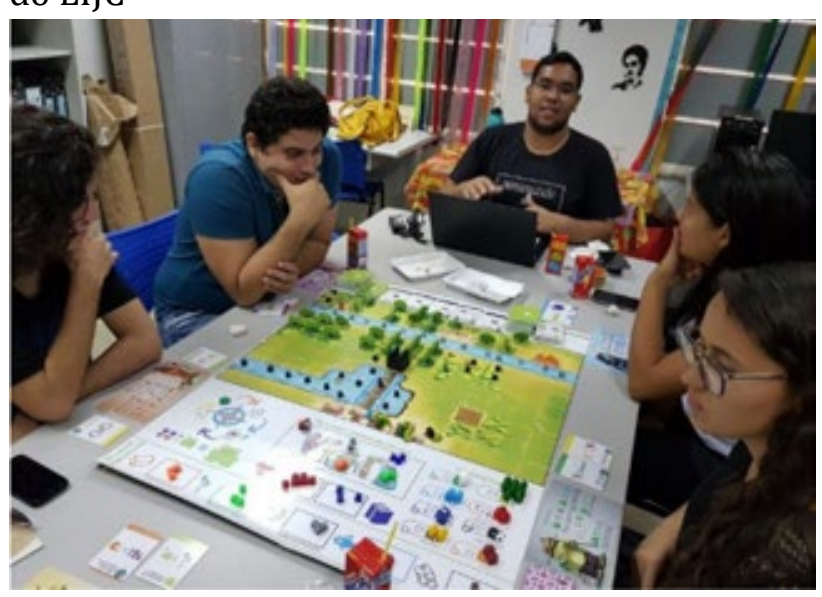

Fonte: Acervo dos autores deste artigo.

Figura 34 - Momento do playtest de Umuechem realizado na UFCA, com membros e colaboradores do LIJC

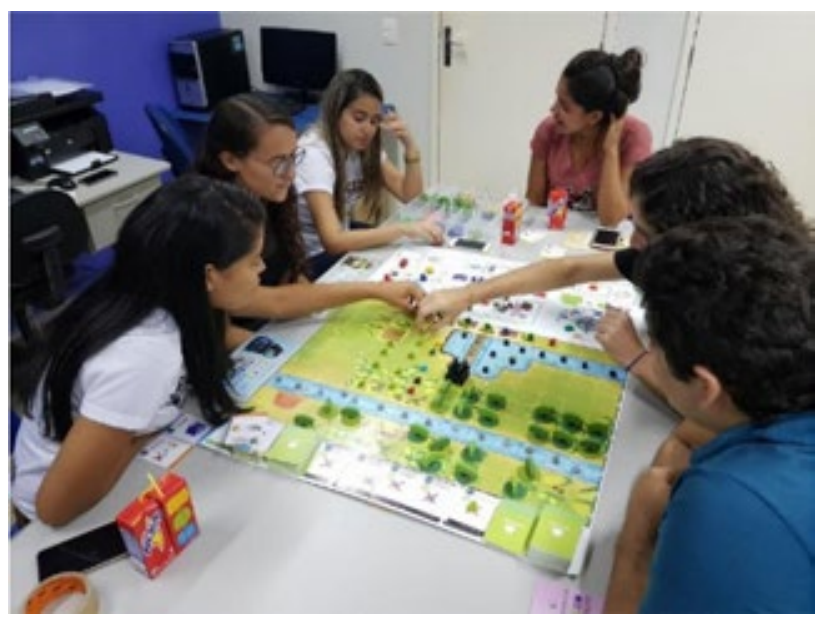

Fonte: Acervo dos autores deste artigo. 


\section{Conclusão}

O processo criativo de criação de jogos não se dá por simples acaso, através de escolhas aleatórias; é fruto de estudo, avaliação e exploração de uma diversidade de possibilidades. Um método como o Ciclo Criativo de Jogos Colaborativos auxilia aos educadores, pesquisadores do campo dos jogos e designers amadores, oferecendo um método sistemático para gerenciar esse processo e descrever a construção de um jogo voltado à educação.

Um jogo cientificamente estruturado representa uma série de opções de design que são pensadas à luz de autores, situações e evidências exploradas por pesquisadores e pesquisadoras, que podem contribuir significativamente para o ambiente que o jogo pretende simular.

Umuechem é um jogo que simula um conflito ecológico distributivo ocorrido no delta do Níger, que envolve os povos tradicionais ogonis, representando, para além da cultura, todo um conjunto de conflitos que podem ser emulados para que os participantes compreendam um pouco da história que se deseja contar (narrativa) e possam tirar do episódio ensinamentos importantes para suas vidas.

Esse é um jogo colaborativo, portanto requer que todos os participantes joguem juntos para atingir metas comuns. As escolhas de design do jogo, em cada uma de suas fases, têm o objetivo de reforçar esse sentido, emulando uma diversidade de problemas que podem ser resolvidos em conjunto, através da busca de consenso, para uma melhor experiência de jogar. A escolha por utilizar jogos do tipo colaborativo vem de encontro à ampliação do sistema de competição, tão comum na vida cotidiana e na educação, em que refletimos sobre o princípio freiriano da construção horizontal do conhecimento como possibilidade de um outro fazer educativo.

Sendo o jogo educativo uma ferramenta que media o processo de ensino-aprendizagem, pensado a partir de conceitos do campo do design, emerge a necessidade que ele seja sistematizado não como um objeto educativo $a$ priori, mas como um jogo do qual emergem os objetivos educacionais. A concepção de um jogo educativo não se desvencilha da educação, mas é um trabalho que exige um esforço interdisciplinar, buscando, na região de fronteira entre os conhecimentos, ideias, conceitos e estudos que possam ser traduzidos em um produto divertido e educativo.

0 processo criativo que origina o jogo exige uma multiplicidade de agentes pelas variadas habilidades e competências necessárias para sua confecção. Ilustração digital, colorização, modelagem 3D, vetorização, pesquisa de materiais e insumos de produção estão ligados à prototipação do jogo, não obstante estas sejam necessidades que podem ser sanadas, plena ou parcialmente, por meio de parcerias e prospecção de serviço.

São as características interdisciplinares, ligadas ao processo produtivo do jogo, que requerem especial atenção. Na leitura deste trabalho é obvio o enlace entre educação, design de jogos, estatística, história, literatura e ciências ambientais. Todos estes conhecimentos necessários para dar vida ao jogo foram possíveis através de muita pesquisa, do engajamento e comprometimento da equipe com o projeto. A confecção de um jogo como esse exige o engajamento de formas interdisciplinares do conhecimento, que possam impactar nos processos de tomada de decisão, para que as referências utilizadas tornem-se claras e estabeleçam relações com o todo que nos propusemos a criar.

Em ambos os níveis, técnico e científico, existe uma imbricação do conhecimento. Todos os envolvidos impactam, com seus diferentes conhecimentos e habilidades, o que o jogo, como produto cognoscente, vem a ser. Sendo o jogo uma manifestação da cultura, além das referências de seus criadores, tem-se de levar em conta, a cada escolha, as possibilidades de leitura que os participantes fazem sobre o jogo e $o$ ato de jogar. 
Escolhas como: a personagem Mineradora ser uma mulher, o personagem Agricultor ser gordo, problemas ambientais causados pelo "desenvolvimento" ocasionado pela fábrica, a representação dos personagens serem sapos. São todas referências escolhidas para que possam ser ensejadas interações entre os participantes. Essas escolhas exigem habilidades estratégicas e comunicacionais para a tomada de decisão, levando em conta o universo dos possíveis participantes, suas referências e histórias de vida.

Como método, o Ciclo Criativo de Jogos Colaborativos se mostra eficaz, em seus dois níveis, para que nós possamos gestar e construir jogos, tendo como premissa a educação, não deixando de lado a ciência e a diversão. Como recomendação para educadores que estejam interessados em criar jogos estruturados por esse método, além de estudá-lo e da composição de equipes criativas, conhecer jogos e jogá-los é fundamental. Uma diversidade de portais, ${ }^{11}$ canais no YouTube, ${ }^{12}$ livros e artigos se debruçam sobre esse tema. Essa é uma questão de reunir saberes técnicos, experiência com jogos e saberes científicos para viabilizar um processo amplo de criação de jogos.

Para trabalhos futuros, pretendemos apresentar novos usos dessa metodologia, descrevendo processos, e também aplicar os jogos criados com este método, além de estudar seus impactos a partir da percepção dos participantes, visando compreender como eles podem contribuir, como ferramenta de mediação, para a tomada de consciência dos participantes sobre questões sensíveis a nossa sociedade.

110 portal americano BoardGame Geek e o portal brasileiro Ludopédia são ambas fontes seguras, com grandes comunidades dispostas a colaborar e com uma enormidade de referências sobre jogos.

12 No YouTube, Canais como Jack Explicador, Pesquisa \& Jogos, Geek \& Sundry, Jogando Offline, The Dice Tower, Celula UFC e On Board são excelentes referências para se ver reviews, mecânicas e análises de jogos produzidos no Brasil e no mundo.

\section{REFERÊNCIAS}

ALIER, Joan Martínez. 0 ecologismo dos pobres: conflitos ambientais e linguagens de valoração. 2 . ed. São Paulo: Contexto, 2015.

ALMEIDA, Marcos Teodorico Pinheiro de. Brincar cooperativo: vivências lúdicas de jogos não competitivos. Petrópolis, RJ: Vozes, 2010.

ALMEIDA, Marcos Teodorico Pinheiro de. Jogos cooperativos: aprendizagens, métodos e práticas. Várzea Paulista, SP: Fontoura, 2011.

ANTUNES, Jeferson. Et al. Considerações e resultados acerca da aplicação da Criativa: metodologia educativa fomentada por meio dos jogos cooperativos. Cadernos de Pesquisa: Pensamento Educacional, Curitiba, v. 11, n. 27, p.15-33 jan./abr. 2016.

ANTUNES, Jeferson. Et al. Ciclo criativo de jogos colaborativos: um método para criação de jogos educativos. Holos, ano 34, v. 2, 2018.

ANTUNES, Jeferson; NASCIMENTO, Verônica Salgueiro do; QUEIROZ, Zuleide Fernandes de. Narrativa crítica acerca do desenvolvimento sustentável: quais relações podemos estabelecer? Revista Eletrônica do Mestrado em Educação Ambiental (REMEA), Rio Grande, RS, v. 34, n. 2, p. 57-65, maio/ago. 2017.

BERBEL, Neusi Aparecida Navas. As metodologias ativas e a promoção da autonomia de estudantes. Semina: Ciências Sociais e Humanas, Londrina, PR, v. 32, n. 1, p. 25-40, jan./jun. 2011.

BRUFFEE, Kenneth A. Sharing our toys: cooperative learning versus collaborative learning. Change: The Magazine of Higher Learning, v. 27, n. 1, p. 12-18, jan./fev. 1995.

CAILOIS, Roger. Os jogos e os homens. Lisboa: Cotovia, 1990.

CASTANHEIRA, Nelson Pereira. Estatística aplicada a todos os níveis. Curitiba: Intersaberes, 2012.

FREIRE, Paulo. Pedagogia da autonomia: saberes necessários à prática educativa. 24. ed. São Paulo: Paz e Terra, 1996.

HUIZINGA, Johan. Homo ludens. São Paulo: Perspectiva, 2000.

KISHIMOTO, Tizuko Morchida. O jogo e a educação infantil. In: KISHIMOTO, Tizuko Morchida. Jogo, brinquedo, brincadeira e a educação. 13. ed. São Paulo: Corteza, 2010. p. 46-63. 
MCGONIAL, Jane. A realidade em jogo: por que os games nos tornam melhores e como eles podem mudar o mundo. Rio de Janeiro: Bestseller, 2012.

SALEN, Katie; ZIMMERMAN, Eric. Regras do jogo: fundamentos do design de jogos. São Paulo: Blucher, 2012.

SCHMITT, Maria Aparecida Nogueira. Do imaginário poético latino-americano o salto antropomórfico de personagens da esfera zoológica. In: BRAGA, Elda Firmo; LIBANORI, Evely Vânia; DIOGO, Rita de Cássia Miranda (org.). Representação animal: diálogos e reflexões literárias. Rio de Janeiro: Oficina da Leitura, 2015. p. 34-53.

SCHELL, Jesse. A arte de game design: o livro original. Rio de Janeiro: Elsevier, 2011.

SCHUYTEMA, Paul. Design de games: uma abordagem prática. São Paulo: Cengage Learning, 2008.

Recebido em: 04/05/2020

Revisado em: 25/06/2020

Aprovado em: 10/08/2020 